\title{
Anomalous Fluctuation of Halogens in Relation to the Pollution Status along Lake Mariout, Egypt
}

\author{
Ghada F. El-Said (D), Gehan M. El Zokm (D), Abeer A. El Sayed (D), Ahmed A. El Ashmawy (D), \\ and Mohamed A. Shreadah
}

National Institute of Oceanography \& Fisheries, NIOF, Cairo, Egypt

Correspondence should be addressed to Gehan M. El Zokm; gehanelzokm@yahoo.com

Received 23 May 2020; Revised 19 October 2020; Accepted 8 December 2020; Published 30 December 2020

Academic Editor: Mohamed Azaroual

Copyright (C) 2020 Ghada F. El-Said et al. This is an open access article distributed under the Creative Commons Attribution License, which permits unrestricted use, distribution, and reproduction in any medium, provided the original work is properly cited.

\begin{abstract}
This paper aimed to study the anomalous fluctuation of halogens with respect to the pollution status in surface water (w), pore water (p), and sediments (s) of Lake Mariout. It provided a framework for understanding the distribution of dissolved and precipitated halogen salts related to the pollution status of the lake. The study cleared out that bromide was only the most abundant halogen in the three studied partitions. On contrast, sediment's partition contained the lowest chloride content. Fluoride minerals, especially, fluorapatites and carbonate-fluorapatite (FAP and CFAP), had high Saturation Index (SI) values in surface water (42.77-51.95 and 16.04-60.89, respectively) and in pore water (51.26-54.60 and 17.52-78.33, respectively). Bromide and chloride were mainly found in the soluble forms in the surface water and pore waters. Iodide salts, $\left(\mathrm{Ca}\left(\mathrm{IO}_{3}\right)_{2}\right.$ and $\mathrm{Ca}\left(\mathrm{IO}_{3}\right)_{2} \cdot 6 \mathrm{H}_{2} \mathrm{O}$ ), were moderately precipitated in surface and pore waters. Thus, SI content reflected that halogens, especially fluoride and iodide, played a vital role in reducing lake pollution. Fluorite $\left(\mathrm{CaF}_{2}\right)$ and sellaïte $\left(\mathrm{MgF}_{2}\right)$ could only be formed in pore water, while calcite and aragonite could be deposited from surface water. In addition, $\mathrm{Cl}$ was mainly found in the forms of $\mathrm{NaCl}$, $\mathrm{CaCl}_{2}, \mathrm{MgCl}_{2}$, and $\mathrm{KCl}$ in surface and pore waters. The multivariate analysis revealed that fluoride precipitate may serve in decreasing the dissolved salt pollution. Multivariate analysis showed that in the long run, the fluoride precipitation in FAP and CFAP can significantly adsorb and absorb various pollutants and can protect the lake from pollution. The ecological risk assessment conducted by calculating the enrichment factor (EF) showed that the lake was still unpolluted. Regarding human health risks, at appropriate levels of human health and safety, the hazard quotient (HQ) and hazard index (HI) of halogens found to be lower than these reported levels. Hence, ingestion and dermal absorption routes of halogens by surface water and sediments did not pose any adverse effects to population reflecting uncontaminated status of Lake Mariout.
\end{abstract}

\section{Introduction}

The water ecosystem in Egypt is rapidly deteriorating due to the increased discharge of heavily polluted domestic sewage, agricultural runoff, and industrial wastewater generated by human activities [1-10]. Egyptian lakes are currently degraded by natural and human activities such as degradation; habitat loss; pollution as they receive great amounts of industrial, municipal, and agricultural wastewater without treatment; and the spread of aquatic plants [11-16]. Although Lake Mariout has recently received government attention, there is still an urgent need for an action plan for sustainable development.
Lake Mariout is recognized as the main part of the old Lake Mareotis [17]. It extends from $29.83^{\circ}-29.98^{\circ} \mathrm{E}$ to $31.05^{\circ}-31.17^{\circ} \mathrm{N}$, with a surface area of approximately $60 \mathrm{~km}^{2}$ and a shallow depth of approximately $1.5 \mathrm{~m}$ (Figure 1). Its location is about $20 \mathrm{~km}$ away from the Mediterranean Sea at the southern part of Alexandria City. It is directly disconnected from the Mediterranean Sea along El-Mex Bay because it is located $2.8 \mathrm{~m}$ below sea level. The El-Mex pumping station pours large amounts of lake water into the Mediterranean Sea through the bay [17]. In the past few years, Lake Mariout has been heavily affected by various human activities, which usually reduce its specific area. However, over the last eighty years, its area decreased drastically from 248 to 


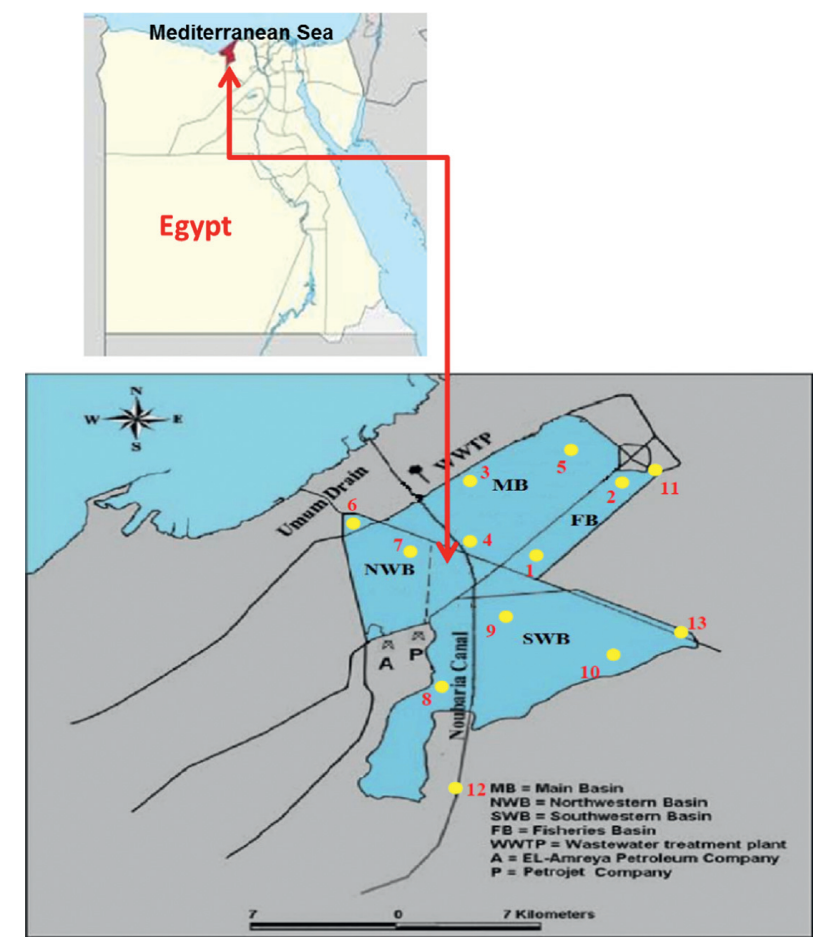

FIGURE 1: Sampling sites along Lake Mariout.

$63.02 \mathrm{~km}^{2}$ due to the land reclamation, and the construction of a series of roads in addition to drainage and navigation canals that divided the lake into basins. These roads and canals have become a physical barrier that prevented the transportation of lake water, fish, and fishermen from a basin to another [17]. Unfortunately, the lake receives large amounts of untreated urban municipal, industrial wastewater, effluents, drainage water, and domestic wastewater from different drains such as El Umoum drain, which directly discharges industrial effluents from different companies such as the Petro jet Company, El-Amreya Petroleum Company, and ElAmreya Company of spinning and weaving, besides the Egyptian Petrochemical Company in addition to domestic and agricultural wastewater into the lake. The El-Qalaa drainage channel discharges $676,000 \mathrm{~m}^{3}$ day ${ }^{-1}$ of primary treatment municipal sewage and agricultural wastewater every day; the El Nubaria Canal discharges industrial, agricultural, and household waste [18]. In addition, some built roads had divided the lake into four separate basins and each area of the physical features and these basins are as follows: the Main Basin, the South West Basin, the North West Basin, and the Fishery Basin, with areas of 25.2, 21.0, 12.6, and $4.2 \mathrm{~km}^{2}$, respectively $[18,19]$. These basins affect the water cycle in the lake, so their role is to minimize the negative impact on lake water quality. Due to the economic importance of Lake Mariout, officials, active civil society, the public, and international development organizations are facing many challenges of sustainable development and environmental improvement. They all share a common interest in developing a set of indicators that play an important role in guiding the planning of this precious ecosystem and overcoming the vulnerability of human health to waste.
Halogens mainly concentrate in the earth's surface reservoirs, including seawater and sediments. The halogen elements show great resemblances to one another in their general chemical behavior and in the properties of their compounds with other elements. They carry out significant roles in the global transformation processes [20]. In addition, halogens naturally exist in the form of monovalent anions, metal-bound salts, silicate minerals, and nonsilicate minerals [20]. Amongst the other halogens, chloride $(\mathrm{Cl})$ exhibits systematically different behavior due to its ionic size or its elemental abundance. Fluorine is strongly electronegative, being the only element in the periodic table that is more electronegative than oxygen. Fluorides (such as fluorite, cryolite, and fluorapatite) traditionally combine the most naturally distributed minerals and usually have many economic uses [21]. Therefore, it enters the social environment through alternative methods (gradual erosion and weathering process) and industry (locally produced phosphate fertilizers, semiconductors, aluminum, special drugs, cosmetics, etc.) [22]. Fluoride has been recorded an abnormal concentration in the seawater along the Mediterranean coast of Egypt. In addition to the large amount of minerals that may be dissolved in the sediment-water interface, the Mediterranean coast of Egypt is also adversely affected by raw sewage, domestic, agricultural, and industrial waste [23]. Bromine is used in the manufacture of agricultural pesticides, disinfectants, film photography, lamps, dyes, textiles, cosmetics, etc. [24].

Iodine is a weakly electronegative redox sensitive element, which is very important in many biochemical pathways. With its low abundance, it is considered an essential element for life [25]. Fluoride (F) is considered as an essential element for oral health and bone formation [26]. In addition, fluoride is functionally an effective metabolic inhibitor. However, it has a constructive interference with the metabolism of proteins, lipids, and carbohydrates in living organisms [27]. Both bromide $(\mathrm{Br})$ and chloride $(\mathrm{Cl})$ exist in the body fluids of animals and mortals, and their abundance depends on their intake and excretion [28]. Although halogens have effective biological functions, high levels of halogens may be toxic. Large amounts of bromide ( $\mathrm{Br}$ ) may cause some adverse symptoms, including nausea and vomiting, abdominal pain, coma, and paralysis [28]. Excessive iodide (I) may cause goiter, hypothyroidism, or hyperthyroidism in exposed people [28]. Ingestion of fluoride can cause nausea, vomiting, abdominal pain, diarrhea, fatigue, drowsiness, coma, convulsions, cardiac arrest, and eventual death [29]. It can also affect physiological processes such as metabolism, growth, and reproduction.

In order to determine the pollution source of a lake, it is useful to analyze the chemical properties of the water and study the main solute sources. The pollution by dissolved salt is related to the large increase of several dissolved salts caused by human activities [30], that is, the total dissolved content in the water system and the increase in the content of anions and cations. The gradual increase in dissolved salt can play an important role in the aquatic environment, but excessive salt may have harmful effects on the ecosystem. Similarly, the chemical balance in the aquatic system, as well 
as the solubility and precipitation of the salt contained, also helps to track pollution [31]. The formation and internal interaction of different soluble and insoluble salts in aquatic systems are affected by the physical and chemical factors of the ecosystem [31]. The behavior of soluble salts in the aquatic systems can provide information about the formation of precipitated salts. The stability of the precipitated salt is affected by the product of the molar concentration of its ions and the equilibrium solubility constant of the precipitated salt. According to previous studies, under alkaline conditions, fluorapatite minerals had an important role in reducing the solubility of calcite in the apatite supernatant and solving the destructive effects of fluoride pollution on Lake Edku in Egypt [32]. Small amounts of bromine are found in certain minerals (such as apatite, amphibole, and biotite) [24]. In addition, calcium hydroxyapatite can remove toxic ions from the water environment [33].

By multivariate analysis, the ecological and environmental multivariate data can assess the environmental impacts and monitor large-scale biodiversity changes [34]. Multivariate analysis is widely used in environmental science. It can help ecologists discover the structure of many characteristics of the data and the previous relatively objective summary for easy understanding. However, it is very complicated in theoretical structure and operation methods.

To the best of our knowledge, relatively little studies have been evaluated for the long-term changes in concentrations of halogens, i.e., bromine, fluorine, chlorine, and iodine and their relative to pollution status in surface water, pore water, and sediments partitions in the polluted Lake Mariout. The aims of this work are to present an overview of the evaluation of halogen's content and to examine the relation of pollution by halogens as well as to find out their possible interactions with dissolved and precipitated salts in Mariout Lake, which is suffering from the huge amounts of different types of waste waters.

\section{Materials and Methods}

2.1. Sampling Sites. Thirteen sampling sites were selected to represent the survey area of Lake Mariout and the incoming drainage (Figure 1). Surface water, sediment pore water, and sediment samples were collected from the thirteen sites. Site 1 and site 2 were affected by the parallel pumping station (pumping water from the Abis drainage $\approx 400,000 \mathrm{~m}^{3}$ day $^{-1}$ and other openings from El Drain [19]. Site 3 represented the combined discharge of El-Qalaa drainage and Western Wastewater Treatment Plant (WWTP). Sites 4-6 belonged to the Main Basin area and were affected by the drainage of ElQalaa and El Umoum. Site 6 represented the contaminated area before the El-Mex pumping station. Site 7 was located in the North West Basin. In addition to salt marshes, it was also directly affected by many industrial and petrochemical companies. The South West shallow basin was adversely affected by the local water sources of El Umoum and El Nubaria drains, and its site was 8-10. Stations 11-13 were located in the El-Qalaa, the El Nubaria, and the El Umoum drains outside the lake. The last three locations were chosen as reference locations to describe the potential pollution of the water discharged into the lake.
2.2. Sampling Processes. Surface water and bottom sediment samples were collected from thirteen selected sites along the lake and the drains of depth range $1.5-2.0 \mathrm{~m}$ by a rubber boat during autumn 2019 (Figure 1). Nitrile gloves were used during the sampling duration.

For water sampling, thirty-nine airtight clean $5 \mathrm{~L}$ polyethylene bottles for water sampling were rinsed three times with double distilled water and then dried. Triplicate collected surface water samples were collected by the Niskin water sampler from each sampling site. However, these surface water samples were not filled in $5 \mathrm{~L}$ cleaned polyethylene bottles in which they can be preserved. Each water sample from the study site was divided into two portions. The first portion was stored in a brown closed polyethylene plastic bottle; the second part was stored in a closed white bottle for the determination of heavy metals. The subdivided samples were carefully transported to the laboratory in an ice box. However, surface water temperature $\left(\mathrm{T}_{\mathrm{w}}\right), \mathrm{pH}$, salinity, and TDS value of water samples were measured on-site using portable equipment (CTD YSI: 566). The dissolved oxygen (DO) sample was fixed in a closed brown glass bottle on-site. Turbidity was measured by using the conventional white enameled Secchi-disc.

For sediment sampling, three replicate sediment samples were collected from 13 sampling sites using a Van-Veen grab sampler, stored in a clean polyethylene bag, and transported to the laboratory in an ice box.

2.3. Sample Preparation. In the laboratory, the first portion of the subdivided surface water was stored in a brown airtight polyethylene plastic bottle at $-20^{\circ} \mathrm{C}$ for halogen analysis. The second portion was divided into two parts, and one of which was stored in a plastic colorless bottle at $-20^{\circ} \mathrm{C}$ to determine phosphorus and silicon in the form of phosphate and silicate. The other part was kept in the refrigerator until the main water components (calcium, magnesium, sodium, potassium, lithium, sulfate, and boron) and heavy metals (copper, manganese, zinc, and iron) were analyzed.

In addition, pore water was extracted from each sediment sample by a centrifuge (Hettich Zentrifugen, Universal 320 R, Andreas Hettich GmbH \& Co.KG, 78532 Tuttlingen, Germany) for $20 \mathrm{~min}$ and at a speed of $10,000 \mathrm{rpm}$ [35].

First, in each extracted pore water sample, $\mathrm{pH}$ and S\%o were detected. Then, one-third of each extracted pore water sample was preserved in a brown polyethylene plastic bottle with a stopper and kept at $-20^{\circ} \mathrm{C}$ for halogen determination. While, two-third portion was preserved in colorless wellclosed plastic bottles and kept at $-20^{\circ} \mathrm{C}$ for analysis of phosphorus, silicon, calcium, magnesium, sodium, potassium, lithium, sulfate, and boron calcium, magnesium sulfate, boron, and heavy metals concentrations $(\mathrm{Cu}, \mathrm{Mn}$, $\mathrm{Zn}$, and $\mathrm{Fe}$ ).

On the other hand, the sediment samples were spread on a clean plastic plate at room temperature and then air dried. After that, the particle size of the air-dried sediment sample was accurately estimated [36]. The digestion of the sediment sample was performed by heating the sample with an acid mixture $\left(3 \mathrm{~mL} \mathrm{HNO}_{3}, 2 \mathrm{~mL} \mathrm{HClO}_{4}\right.$, and $\left.1 \mathrm{~mL} \mathrm{HF}\right)$ at $70^{\circ} \mathrm{C}$ in 
a closed Teflon container. The extraction of fluoride, bromide, and iodide from sediment samples was carried out after the fusion of $\mathrm{Na}_{2} \mathrm{CO}_{3}$ with each sediment sample $[37,38]$.

2.4. Samples Analyses. The carbonate and bicarbonate of surface and pore waters were determined in the laboratory by the titration method $[39,40]$. $\mathrm{pH}$, and TDS values of the pore water were measured in the laboratory using portable equipment (CTD YSI: 566). From the salinity value, chlorosity $(\mathrm{Cl})$ in the surface and pore waters and chlorinity $(\mathrm{Cl} \%)$ were effectively calculated [39]. The DO of water samples was accurately measured by Winkler's method [41]. Porosity was measured based on the weight difference between dry and wet sediment samples [42]. Calcium and magnesium in surface and pore waters and digested sediment samples were carefully determined by the titrimetric method using Eriochrome Black $\mathrm{T}$ and Murexide indicators [43]. Sodium, potassium, and lithium contents in surface and pore waters and digested sediment samples were estimated by the flame photometer instrument (lame139 photometer PFP, JENWAY 7). Inorganic phosphorus and total phosphorus contents in the surface and pore waters and sediment samples were determined $[43,44]$. Silicate was measured in the surface and pore waters and digested sediment samples by the calorimetric method [39]. Curcumin colorimetry was used to determine boron in surface water, pore water, and digested sediment [43]. The turbidity method was used to estimate sulfate in the surface water and pore water and digested sediment samples [43]. The heavy metals ( $\mathrm{Cu}, \mathrm{Mn}, \mathrm{Zn}$, and $\mathrm{Fe}$ ) dissolved in the surface and pore water samples were extracted with chelating resin and measured with an atomic absorption spectrophotometer (GBC, Savant AA, Scientific equipment serial no. A 7275 GBC) [45]. Fluoride concentration was determined by the colorimetric method using the zirconium alizarin red $\mathrm{S}$ method [46]. The bromide was determined by titration using a thiosulfate solution [41]. The catalytic reduction method using the Ce(IV)-As(III) was applied to determine the iodine concentration [43]. The chloride content in sediments was established by Mohr's method [47].

2.5. Quality Control and Quality Assurance. A sediment reference material (IAEA-405, International Atomic Energy Agency, Vienna, Austria) was used to determine the sediment sample's quality control/quality assurance. The recovery percentages for the selected metals from the standard reference material were in the range of $97.0-101.1 \%$. For each variable, an examined calibration procedure of three external standards was performed. One of the external standards must be of a concentration near, but above, the method detection limit. The other concentrations should correspond to the range of a variable concentration expected in the sample. The working calibration curve was verified on each working shift by the measurement of one or more calibration standards.
2.6. Saturation Index (SI). The Saturation Index (SI) of 23 and 15 structures in surface water and pore water samples were calculated respectively $[23,48]$.

It can be calculated from the division of the product of the molar concentrations (IAP; [49]) of their component by their equilibrium solubility constant (Table 1). Moreover, SI of some minerals such as anhydrite $\left(\mathrm{CaSO}_{4}\right)$, gypsum $\left(\mathrm{CaSO}_{4} \cdot 2 \mathrm{H}_{2} \mathrm{O}\right)$, calcium phosphate $\left(\mathrm{Ca}_{3}\left(\mathrm{PO}_{4}\right)_{2}\right)$, magnesium phosphate $\left(\mathrm{Mg}_{3}\left(\mathrm{PO}_{4}\right)_{2}\right)$, calcite $\left(\mathrm{CaCO}_{3}\right)$, aragonite $\left(\mathrm{CaCO}_{3}\right)$, dolomite $\left(\mathrm{CaMg}\left(\mathrm{CO}_{3}\right)_{2}\right)$, magnesite $\left(\mathrm{MgCO}_{3}\right)$, fluorapatite (FAP; $\left.\mathrm{Ca}_{5}\left(\mathrm{PO}_{4}\right)_{3} \mathrm{~F}\right)$, hydroxyapatite (HAP; $\left.\mathrm{Ca}_{5}\left(\mathrm{PO}_{4}\right)_{3} \mathrm{OH}\right)$, octacalcium phosphate (OCP; $\mathrm{Ca}_{4} \mathrm{H}\left(\mathrm{PO}_{4}\right)_{3} \cdot 2.5 \mathrm{H}_{2} \mathrm{O}$ ), and carbonatefluorapatite (CFAP; $\mathrm{Ca}_{10}\left(\mathrm{PO}_{4}\right)_{5}\left(\mathrm{CO}_{3}\right) \mathrm{F}_{2.72}(\mathrm{OH})_{0.28}$ ), besides some precipitated salts $\left(\mathrm{Fe}(\mathrm{OH})_{2}, \mathrm{Fe}(\mathrm{OH})_{3}, \mathrm{FePO}_{4} \cdot 2 \mathrm{H}_{2} \mathrm{O}\right.$, $\mathrm{Mg}(\mathrm{OH})_{2}, \mathrm{Mg}_{3}\left(\mathrm{PO}_{4}\right)_{2}, \mathrm{Mn}\left(\mathrm{IO}_{3}\right)_{2}, \mathrm{KIO}_{4}, \mathrm{KCIO}_{4}, \mathrm{ZnCO}_{3}$, $\mathrm{ZnCO}_{3} \cdot \mathrm{H}_{2} \mathrm{O}, \mathrm{Zn}(\mathrm{OH})_{2}$, and $\left.\mathrm{Zn}\left(\mathrm{IO}_{3}\right)_{2} \cdot 2 \mathrm{H}_{2} \mathrm{O}\right)$, was calculated by the following equation [23, 48]:

$$
\mathrm{SI}=\log \left(\frac{\mathrm{IAP}}{K_{\mathrm{sp}}}\right),
$$

where IAP and $K_{\text {sp }}$ were the product of the ion activity and the equilibrium solubility constant of each precipitated salt or mineral. SI values represented the under saturation $(\mathrm{SI}<1)$ or over saturation $(\mathrm{SI}>1)$ situation of each precipitated salt or mineral.

2.7. Palmer's Method and Piper Ternary Diagram. The dissolved salts in the surface and pore waters in the investigated area were utilized by Palmer's method and piper ternary diagram. Palmer's method by using the mill equivalent percentage of the major anions $\left(\mathrm{Cl}^{-}, \mathrm{SO}_{4}{ }^{-2}\right.$, and $\left.\mathrm{HCO}_{3}^{-}\right)$and cations $\left(\mathrm{K}^{+}, \mathrm{Na}^{+}, \mathrm{Ca}^{+2}\right.$, and $\left.\mathrm{Mg}^{+2}\right)$ [50]. This method assumed that the concentration of positive ions and negative ions are in equilibrium; i.e., the sum of the concentrations of positive ions in meq $\mathrm{L}^{-1}$ is equal to the sum of the concentrations of negative of ions considering only the major ions. This hypothesis can be verified by converting the average ion concentration of surface water and pore water along the study area from $\mathrm{mg} \mathrm{L}^{-1}$ in Table 2 to meq $\mathrm{L}^{-1}$. Then, the concentrations were further converted into a percentage of each ion in relation to the total concentration of positive ions in the case of a positive ion and in relation to the total concentration of negative ions in the case of a negative ion. The percentage of each cation and anion was represented in two rectangles in $\mathrm{cm}$ to evaluate the relative formed soluble salts. Piper ternary diagram explores the origin of the dissolved salts in surface and pore waters of the lake water besides the effects of drainage sources on them [55].

2.8. Multivariate Analysis. Multivariate analysis including correlation, multiple stepwise linear regression, and cluster analysis has been used to predict the role of halogens in the pollution status of Lake Mariout. Multivariate analysis can be used in monitoring research because they can reduce the 
TABLE 1: The hypothetical precipitated salts in surface and pore waters along Lake Mariout.

\begin{tabular}{|c|c|c|c|c|c|c|c|c|c|c|c|c|c|}
\hline Site & 1 & 2 & 3 & 4 & 5 & 6 & 7 & 8 & 9 & 10 & 11 & 12 & 13 \\
\hline \multicolumn{14}{|c|}{ SI of precipitated salts and minerals } \\
\hline Surface water & & & & & & & & & & & & & \\
\hline Calcite & 1.28 & 1.38 & 3.40 & 1.46 & 2.36 & 3.03 & 2.95 & 2.97 & 2.05 & 2.58 & 3.12 & 1.26 & 3.11 \\
\hline Aragonite & 1.03 & 1.12 & 3.15 & 1.20 & 2.11 & 2.78 & 2.70 & 2.72 & 1.80 & 2.33 & 2.87 & 1.01 & 2.86 \\
\hline $\mathrm{CaSO}_{4} \cdot 0.5 \mathrm{H}_{2} \mathrm{O}$ & 2.08 & 1.88 & 1.26 & 1.57 & 1.56 & 1.55 & 1.70 & 1.79 & 1.99 & 1.71 & 1.15 & 0.75 & 1.81 \\
\hline $\mathrm{CaSO}_{4} \cdot 2 \mathrm{H}_{2} \mathrm{O}$ & 1.96 & 1.76 & 1.14 & 1.44 & 1.43 & 1.43 & 1.58 & 1.67 & 1.87 & 1.58 & 1.03 & 0.63 & 1.69 \\
\hline $\mathrm{Ca}_{3}\left(\mathrm{PO}_{4}\right)_{2}$ & 24.86 & 24.24 & 24.24 & 24.24 & 24.24 & 24.24 & 24.24 & 24.24 & 24.24 & 24.24 & 24.24 & 24.24 & 24.24 \\
\hline $\mathrm{Ca}\left(\mathrm{IO}_{3}\right)_{2}$ & 1.57 & 1.37 & 1.37 & 1.37 & 1.37 & 1.37 & 1.37 & 1.37 & 1.37 & 1.37 & 1.37 & 1.37 & 1.37 \\
\hline $\mathrm{Ca}\left(\mathrm{IO}_{3}\right)_{2} \cdot 6 \mathrm{H}_{2} \mathrm{O}$ & 10.06 & 9.86 & 9.86 & 9.86 & 9.86 & 9.86 & 9.86 & 9.86 & 9.86 & 9.86 & 9.86 & 9.86 & 9.86 \\
\hline $\mathrm{OCP}$ & 39.64 & 35.69 & 35.69 & 35.69 & 35.69 & 35.69 & 35.69 & 35.69 & 35.69 & 35.69 & 35.69 & 35.69 & 35.69 \\
\hline HAP & 45.74 & 43.49 & 43.49 & 43.49 & 43.49 & 43.49 & 43.49 & 43.49 & 43.49 & 43.49 & 43.49 & 43.49 & 43.49 \\
\hline FAP & 42.77 & 50.36 & 50.38 & 51.95 & 51.71 & 51.31 & 50.90 & 49.82 & 51.31 & 50.81 & 49.03 & 50.95 & 51.63 \\
\hline CFAP & 60.89 & 16.85 & 17.86 & 18.18 & 17.84 & 19.02 & 18.83 & 17.85 & 17.64 & 18.59 & 16.04 & 18.24 & 19.14 \\
\hline $\mathrm{Fe}(\mathrm{OH})_{2}$ & 11.96 & 12.17 & 11.96 & 11.89 & 12.08 & 10.59 & 11.76 & 11.58 & 10.07 & 11.92 & 12.05 & 11.99 & 11.52 \\
\hline $\mathrm{Fe}(\mathrm{OH})_{3}$ & 35.44 & 35.64 & 35.43 & 35.36 & 35.55 & 34.07 & 35.24 & 35.05 & 33.54 & 35.39 & 35.52 & 35.46 & 34.99 \\
\hline $\mathrm{FePO}_{4} \cdot 2 \mathrm{H}_{2} \mathrm{O}$ & 10.53 & 10.74 & 10.53 & 10.46 & 10.65 & 9.16 & 10.33 & & 8.64 & & & 10.56 & 10.08 \\
\hline $\mathrm{Mg}(\mathrm{OH})_{2}$ & 12.15 & 12.06 & 11.31 & 11.71 & 11.73 & 11.59 & 11.79 & 11.88 & 11.70 & 11.83 & 11.51 & 11.52 & 11.68 \\
\hline $\mathrm{Mg}_{3}\left(\mathrm{PO}_{4}\right)_{2}$ & 0.85 & 13.45 & 11.21 & 12.40 & 12.45 & 12.05 & 12.64 & 12.91 & 12.36 & 12.76 & 11.80 & 11.84 & 12.29 \\
\hline $\mathrm{Mn}\left(\mathrm{IO}_{3}\right)_{2}$ & 0.25 & 2.43 & 3.54 & 3.03 & 2.47 & 3.12 & 2.26 & 0.55 & 1.83 & 1.98 & 0.64 & 2.62 & 0.42 \\
\hline $\mathrm{KIO}_{4}$ & 5.76 & 5.70 & 5.52 & 5.49 & 5.65 & 5.64 & & & 5.51 & & 4.89 & 5.51 & 5.48 \\
\hline $\mathrm{KCIO}_{4}$ & 4.95 & 4.89 & 4.71 & 4.68 & 4.84 & 4.83 & 4.78 & 4.73 & 4.70 & 4.79 & 4.08 & 4.70 & 4.67 \\
\hline $\mathrm{ZnCO}_{3}$ & 4.14 & 4.04 & 6.13 & 4.55 & 5.60 & 5.60 & 5.86 & 5.73 & 4.91 & 5.30 & 6.59 & 4.72 & 5.81 \\
\hline $\mathrm{ZnCO}_{3} \cdot \mathrm{H}_{2} \mathrm{O}$ & -0.18 & -0.27 & 1.81 & 0.24 & 1.28 & 1.28 & 1.54 & 1.42 & 0.60 & 0.99 & 2.27 & 0.41 & 1.49 \\
\hline $\mathrm{Zn}(\mathrm{OH})_{2}$ & 11.98 & 11.89 & 11.99 & 12.10 & 12.54 & 11.94 & 12.23 & 12.32 & 12.16 & 12.07 & 12.49 & 12.27 & 12.03 \\
\hline $\mathrm{Zn}\left(\mathrm{IO}_{3}\right)_{2} \cdot 2 \mathrm{H}_{2} \mathrm{O}$ & 3.66 & 3.57 & 3.67 & 3.78 & 4.22 & 3.62 & 3.91 & 4.00 & 3.83 & 3.75 & 4.17 & 3.95 & 3.71 \\
\hline \multicolumn{14}{|l|}{ Pore water } \\
\hline Fluorite & 2.00 & 2.11 & 1.06 & 1.95 & 3.46 & 3.09 & 3.45 & 3.17 & 2.28 & 2.46 & 3.07 & 3.65 & 2.77 \\
\hline $\mathrm{CaSO}_{4} \cdot 0.5 \mathrm{H}_{2} \mathrm{O}$ & 3.70 & 1.77 & 1.90 & 2.00 & 1.68 & 1.78 & 2.02 & 2.55 & 2.03 & 2.12 & 1.91 & 1.79 & 2.11 \\
\hline $\mathrm{CaSO}_{4} \cdot 2 \mathrm{H}_{2} \mathrm{O}$ & 3.58 & 1.65 & 1.78 & 1.88 & 1.55 & 1.66 & 1.90 & 2.43 & 1.91 & 2.00 & 1.78 & 1.67 & 1.99 \\
\hline $\mathrm{Ca}_{3}\left(\mathrm{PO}_{4}\right)_{2}$ & 29.58 & 24.24 & 24.24 & 24.24 & 24.24 & 24.24 & 24.24 & 24.24 & 24.24 & 24.24 & 24.24 & 24.24 & 24.24 \\
\hline $\mathrm{Ca}\left(\mathrm{IO}_{3}\right)_{2}$ & 3.15 & 1.37 & 1.37 & 1.37 & 1.37 & 1.37 & 1.37 & 1.37 & 1.37 & 1.37 & 1.37 & 1.37 & 1.37 \\
\hline $\mathrm{Ca}\left(\mathrm{IO}_{3}\right)_{2} \cdot 6 \mathrm{H}_{2} \mathrm{O}$ & 11.64 & 9.86 & 9.86 & 9.86 & 9.86 & 9.86 & 9.86 & 9.86 & 9.86 & 9.86 & 9.86 & 9.86 & 9.86 \\
\hline $\mathrm{OCP}$ & 45.94 & 35.69 & 35.69 & 35.69 & 35.69 & 35.69 & 35.69 & 35.69 & 35.69 & 35.69 & 35.69 & 35.69 & 35.69 \\
\hline HAP & 53.61 & 43.49 & 43.49 & 43.49 & 43.49 & 43.49 & 43.49 & 43.49 & 43.49 & 43.49 & 43.49 & 43.49 & 43.49 \\
\hline FAP & 51.26 & 52.95 & 53.99 & 52.70 & 54.60 & 53.18 & 53.27 & 53.38 & 53.21 & 53.11 & 54.20 & 53.73 & 53.91 \\
\hline CFAP & 78.33 & 17.75 & 20.68 & 17.52 & 20.49 & 20.78 & 19.90 & 20.15 & 19.63 & 20.26 & 21.21 & 20.24 & 20.60 \\
\hline $\mathrm{MgF}_{2}$ & 2.99 & 1.38 & 1.77 & 0.60 & 2.62 & 2.32 & 0.95 & 2.09 & 2.12 & 2.43 & 2.22 & 2.51 & 2.03 \\
\hline $\mathrm{Mg}(\mathrm{OH})_{2}$ & 13.95 & 14.39 & 14.08 & 14.00 & 14.28 & 14.20 & 13.46 & 14.25 & 14.18 & 14.38 & 14.12 & 13.91 & 14.14 \\
\hline $\mathrm{Mg}_{3}\left(\mathrm{PO}_{4}\right)_{2}$ & 9.87 & 24.42 & 24.17 & 23.55 & 24.69 & 22.07 & 21.28 & 23.17 & 22.43 & 22.60 & 23.87 & 21.32 & 23.78 \\
\hline $\mathrm{KIO}_{4}$ & 5.64 & 5.68 & 5.75 & 5.57 & 5.61 & 5.60 & 5.70 & 5.66 & 5.58 & 5.71 & 5.51 & 5.43 & 5.64 \\
\hline $\mathrm{KCIO}_{4}$ & 4.83 & 4.87 & 4.94 & 4.76 & 4.80 & 4.79 & 4.89 & 4.85 & 4.77 & 4.90 & 4.70 & 4.61 & 4.83 \\
\hline
\end{tabular}

cost of further environmental investigations [56-58]. The multivariate analysis using the correlation matrix with a correlation coefficient $(r)$, multiple stepwise linear regression with a coefficient $(R)$, and cluster (tree clustering) at a significance level of $p \leq 0.05$ is estimated by STATISTICA 99 edition. At the same time, the principal component (PCA) can be estimated through SPSS 15 evaluation.

2.9. Enrichment Factor (EF). EF of the determined elements (Ca, Mg, Na, K, Li, B, P, Cu, Zn, Mn, Fe, F, Cl, Br, and I) was calculated by using the equations described (equations (2) and (3)) $[59,60]$ :

$$
\mathrm{EF}=\frac{C_{\mathrm{m}} \text { sample }}{\left(\text { Median } C_{\mathrm{m}} \text { Background }+2 \times \mathrm{MADC}_{\mathrm{m}} \text { Background }\right)},
$$

where $C_{\mathrm{m}}$ was the element concentration, Median $C_{\mathrm{m}}$ Background represented median concentration of an element in the background, and MAD $C_{\mathrm{m}}$ Background was the median absolute deviation from the median calculated from the given equation:

$$
\operatorname{MAD}=\operatorname{median}\left(\left|x_{i}-\operatorname{median}_{j}\left(x_{j}\right)\right|\right) .
$$

The EF values were classified into five categories: deficiency to minimal $(\mathrm{EF}<2)$, moderate $(2<\mathrm{EF}<5)$, significant $(5<\mathrm{EF}<20)$, very high $(20<\mathrm{EF}<40)$, and extremely high enrichment $(\mathrm{EF}>40)$.

2.10. Human Health Risk Assessment. The human health hazard of surface water and sediment ingestion and dermal contact was assessed by using the estimated daily intake 
TAвLe 2: Distribution of the studied variables in surface water $(\mathrm{w})$ and their chlorinity ratios along Lake Mariout.

\begin{tabular}{|c|c|c|c|c|c|c|c|c|}
\hline Determined variables & Minimum & Site & Maximum & Site & Average & SD & Seawater $^{\mathrm{a}}$ & Lake Mariout $^{\mathrm{b}, \mathrm{c}, \mathrm{d}}$ \\
\hline \multicolumn{9}{|c|}{ Physicochemical variables } \\
\hline $\mathrm{T}_{\mathrm{w}}$ & 13.7 & 10 & 15.34 & 11 & 17.59 & 1.34 & & \\
\hline Salinity $\left(\mathrm{S} \% \mathrm{o}_{\mathrm{w}}\right)$ & 2.3 & 13 & 7.9 & 1 & 4.89 & 1.52 & & \\
\hline Chlorinity $\left(\mathrm{Cl}_{0} \mathrm{o}_{\mathrm{w}}\right)$ & 2.05 & 13 & 7.1 & 1 & 4.38 & 1.37 & 18.98 & \\
\hline $\operatorname{TDS}_{\mathrm{w}}\left(\mathrm{mg} \mathrm{L}^{-1} \mathrm{l}\right)$ & 2463.5 & 13 & 7683 & 1 & 4850.3 & 1528.74 & & \\
\hline Turbidity (NTU) & 1.66 & 8 & 38.5 & 12 & 12.96 & 11.74 & & \\
\hline $\mathrm{DO}_{\mathrm{w}}\left(\mathrm{mg} \mathrm{L}^{-1} \mathrm{l}\right)$ & 0 & 6 & 12.41 & 2 & 6.05 & 4.83 & & $2.14-5.63^{\mathrm{d}}$ \\
\hline $\mathrm{pH}_{\mathrm{w}}$ & 7.44 & 13 & 8.99 & 2 & & & & $7.10-8.60^{\mathrm{d}}$ \\
\hline $\mathrm{CO}_{3 \mathrm{w}}\left(\mathrm{mg} \mathrm{L}^{-1}\right)$ & 1.2 & $1 \& 2$ & 115.2 & 3 & 31 & 38.8 & & \\
\hline $\mathrm{HCO}_{3 \mathrm{w}}\left(\mathrm{mg} \mathrm{L}^{-1}\right)$ & 78.08 & 3 & 190.32 & 12 & 114.7 & 32.1 & & \\
\hline $\mathrm{B}_{\mathrm{w}}\left(\mathrm{mg} \mathrm{L}^{-1}\right)$ & 0.5 & 7 & 16.61 & 1 & 6.91 & 4.11 & 4.5 & \\
\hline $\mathrm{P}_{\mathrm{w}}\left(\mu \mathrm{g} \mathrm{L}^{-1}\right)$ & 0.03 & 8 & 1.26 & 5 & 0.29 & 0.33 & & \\
\hline $\mathrm{Si}_{\mathrm{w}}\left(\mu \mathrm{g} \mathrm{L}^{-1}\right)$ & 0.09 & 12 & 6.99 & 4 & 3.17 & 1.91 & & \\
\hline $\mathrm{Ca}_{\mathrm{w}}\left(\mathrm{mg} \mathrm{L}^{-1}\right)$ & 60.92 & 12 & 352.7 & 8 & 177.03 & 73.5 & 400 & $54.9,81.8-146.4^{\mathrm{d}}$ \\
\hline $\mathrm{Mg}_{\mathrm{w}}\left(\mathrm{mg} \mathrm{L}^{-1}\right)$ & 97.25 & 3 & 666.15 & 1 & 286.84 & 160.02 & 1272 & 120.1 \\
\hline $\mathrm{Na}_{\mathrm{w}}\left(\mathrm{mg} \mathrm{L}^{-1}\right)$ & 231 & 11 & 1420 & 1 & 1011.15 & 297.2 & 10556 & 1033.2 \\
\hline $\mathrm{K}_{\mathrm{w}}\left(\mathrm{mg} \mathrm{L}^{-1}\right)$ & 8 & 11 & 59 & 1 & 37.69 & 12.3 & 380 & 58.5 \\
\hline $\mathrm{Li}_{\mathrm{w}}\left(\mathrm{mg} \mathrm{L}^{-1}\right)$ & 0.139 & 11 & 0.17 & 1 & 0.154 & 0.01 & 0.17 & \\
\hline $\mathrm{SO}_{4 \mathrm{w}}\left(\mathrm{mg} \mathrm{L}^{-1}\right)$ & 19.78 & 12 & 341.11 & 9 & 168.56 & 94.88 & 2649 & 424.5 \\
\hline $\mathrm{Cu}_{\mathrm{w}}\left(\mu \mathrm{g} \mathrm{L}^{-1}\right)$ & 2.04 & 3 & 6.21 & 7 & 3.17 & 1.13 & 7 & \\
\hline $\mathrm{Mn}_{\mathrm{w}}\left(\mu \mathrm{g} \mathrm{L}^{-1}\right)$ & 0.01 & $8 \& 13$ & 19.8 & 3 & 3.15 & 5.54 & 10 & \\
\hline $\mathrm{Fe}_{\mathrm{w}}\left(\mu \mathrm{g} \mathrm{L}^{-1}\right)$ & 0.09 & 9 & 13.92 & 13 & 6.9 & 4.19 & 40 & \\
\hline $\mathrm{Zn}_{\mathrm{w}}\left(\mu \mathrm{g} \mathrm{L}^{-1}\right)$ & 5.27 & 2 & 23.67 & 5 & 10.85 & 5.78 & 20 & \\
\hline $\mathrm{F}_{\mathrm{w}}\left(\mathrm{mg} \mathrm{L}^{-1}\right)$ & 0.15 & 11 & 3.96 & 12 & 2.04 & 1.17 & 1.3 & \\
\hline $\mathrm{Cl}_{\mathrm{w}}\left(\mathrm{mg} \mathrm{L}^{-1}\right)$ & 2048 & 13 & 7284 & 1 & 4397 & 1400 & 18980 & \\
\hline $\mathrm{Br}_{\mathrm{w}}\left(\mathrm{mg} \mathrm{L}^{-1}\right)$ & 5.06 & $12 \& 13$ & 54.1 & 5 & 18.13 & 18.91 & 65 & 5.92 \\
\hline $\mathrm{I}_{\mathrm{w}}\left(\mu \mathrm{g} \mathrm{L}^{-1}\right)$ & 5.66 & 10 & 54.1 & 4 & 11.08 & 12.96 & 60 & \\
\hline \multicolumn{9}{|l|}{ Ion chlorinity ratio } \\
\hline $\mathrm{Ca}_{\mathrm{w}} / \mathrm{Cl}_{\mathrm{w}}$ & $1.70 E-02$ & 12 & $1.00 E-01$ & 13 & $4.40 E-02$ & $2.40 E-02$ & $2.13 E-02$ & $3.35 E-02$ \\
\hline $\mathrm{Mg}_{\mathrm{w}} / \mathrm{Cl}_{\mathrm{w}}$ & $2.50 E-02$ & 3 & $1.10 E-01$ & 13 & $6.40 E-02$ & $2.30 E-02$ & $6.69 E-02$ & $7.33 E-02$ \\
\hline $\mathrm{Na}_{\mathrm{w}} / \mathrm{Cl}_{\mathrm{w}}$ & $6.50 E-02$ & 11 & $3.80 E-01$ & 13 & $2.40 E-01$ & $7.20 E-02$ & $5.60 E-01$ & $6.35 E-01$ \\
\hline $\mathrm{K}_{\mathrm{w}} / \mathrm{Cl}_{\mathrm{w}}$ & $2.20 E-03$ & 11 & $1.50 E-02$ & 13 & $8.90 E-03$ & $2.90 E-03$ & $2.10 E-02$ & $3.60 E-02$ \\
\hline $\mathrm{Li}_{\mathrm{w}} / \mathrm{Cl}_{\mathrm{w}}$ & $2.40 E-05$ & 1 & $7.00 E-05$ & 13 & $3.80 E-05$ & $1.10 E-05$ & $9.39 E-06$ & \\
\hline $\mathrm{SO}_{4 \mathrm{w}} / \mathrm{Cl}_{\mathrm{w}}$ & $5.40 E-03$ & 12 & $1.10 E-01$ & 13 & $4.20 E-02$ & $3.10 E-02$ & $1.40 E-01$ & $2.60 E-01$ \\
\hline $\mathrm{B}_{\mathrm{w}} / \mathrm{Cl}_{\mathrm{w}}$ & $9.78 E-05$ & 7 & $3.32 E-03$ & 9 & $6.70 E-03$ & $1.70 E-03$ & $8.95 E-04$ & \\
\hline $\mathrm{F}_{\mathrm{w}} / \mathrm{Cl}_{\mathrm{w}}$ & $4.30 E-05$ & 11 & $1.40 E-03$ & 13 & $5.40 E-04$ & $4.20 E-04$ & $6.70 E-05$ & \\
\hline $\mathrm{Br}_{\mathrm{w}} / \mathrm{Cl}_{\mathrm{w}}$ & $1.40 E-03$ & 12 & $1.60 E-02$ & 9 & $4.40 E-03$ & $5.00 E-03$ & $3.50 E-03$ & $3.60 E-05$ \\
\hline $\mathrm{I}_{\mathrm{w}} / \mathrm{Cl}_{\mathrm{w}}$ & $9.40 E-04$ & 1 & $1.60 E-02$ & 4 & $3.00 E-03$ & $4.00 E-03$ & & \\
\hline
\end{tabular}

${ }^{\mathrm{a}}[51] ;{ }^{\mathrm{b}}$ and ${ }^{\mathrm{c}}[52,53] ;{ }^{\mathrm{d}}[54]$.

(EDI), hazard quotient (HQ), and hazard index (HI) as given in equations (4)-(11).

2.10.1. For Surface Water. Estimated daily intake of surface water ingestion and dermal contact $\left(\mathrm{EDI}_{\text {Ingw }}\right.$ and $\left.\mathrm{EDI}_{\text {Dermw }}\right)$ were computed by the following equations [61]:

$$
\begin{aligned}
\mathrm{EDI}_{\text {Ingw }}(\mathrm{mg} / \mathrm{kg} / \text { day }) & =\frac{(\mathrm{CW} \times \mathrm{CR} \times \mathrm{ET} \times \mathrm{EF} \times \mathrm{ED})}{(\mathrm{AT} \times \mathrm{BW})}, \\
\mathrm{EDI}_{\text {Dermw }}(\mathrm{mg} / \mathrm{kg} / \text { day }) & =\frac{(\mathrm{CW} \times \mathrm{SA} \times \mathrm{PC} \times \mathrm{ET} \times \mathrm{EF} \times \mathrm{ED} \times \mathrm{CF})}{(\mathrm{AT} \times \mathrm{BW})},
\end{aligned}
$$

where CW was the element concentration in water $\left(\mathrm{mg} \mathrm{L}^{-1}\right)$, CR was the contact time $\left(50 \mathrm{~mL} \mathrm{~h}^{-1}\right)$, ET was the exposure time $\left(2.6 \mathrm{~h} \mathrm{day}^{-1}\right)$, EF was the exposure frequency (7 day year $\left.^{-1}\right)$, ED was the exposure duration (60 year), AT was the average time $\left(60 \times 365\right.$ day year $\left.{ }^{-1}\right)$, BW was $(70.7 \mathrm{~kg})$, SA was the skin surface area $\left(5,700 \mathrm{~cm}^{-2}\right)$, PC was the dermal permeability constant $\left(0.001 \mathrm{~cm} \mathrm{~h}^{-1}\right)$, and $\mathrm{CF}$ was the conversion factor for water $\left(1.0 \times 10^{-6} \mathrm{~kg} \mathrm{mg}^{-1}\right)$ [62-65].

2.10.2. For Sediment. Estimated daily intake of sediment by ingestion and dermal contact $\left(\mathrm{EDI}_{\text {Ings }}\right.$ and $\left.\mathrm{EDI}_{\text {Derms }}\right)$ were calculated according to the following equations [60]:

$$
\begin{aligned}
& \mathrm{EDI}_{\text {IngS }}(\mathrm{mg} / \mathrm{kg} / \text { day })=\frac{\left(\mathrm{CS} \times \operatorname{Ing}_{\mathrm{S}} \times \mathrm{RAF}_{\mathrm{S}} \times \mathrm{EF}_{\mathrm{S}}\right)}{(\mathrm{AT} \times \mathrm{BW})}, \\
& \mathrm{EDI}_{\text {DermS }}(\mathrm{mg} / \mathrm{kg} / \text { day })=\frac{\left(\mathrm{CS} \times \operatorname{Ing}_{\mathrm{S}} \times \mathrm{ED} \times \mathrm{SA} \times \mathrm{AF} \times \mathrm{ABS}\right)}{(\mathrm{AT} \times \mathrm{BW})},
\end{aligned}
$$

where CS was the concentration of the contaminant in sediment $\left(\mathrm{mg} \mathrm{g}^{-1}\right), \mathrm{Ing}_{\mathrm{S}}$ was the ingestion rated of sediment $\left(8.0 \times 10^{-5} \mathrm{mg} \mathrm{kg}^{-1}\right), \mathrm{RAF}_{\mathrm{S}}$ was the relative absorption factor of sediment (0.58), $\mathrm{EF}_{\mathrm{S}}$ was the exposure frequency (30 day 
year $\left.{ }^{-1}\right), \mathrm{AF}$ was the adherence factor $\left(0.07 \mathrm{mg} \mathrm{cm}^{-2}\right)$, and ABS was the dermal absorption factor (0.001 unit less) $[65,66]$.

Hazard index (HI) is the total chronic hazard attributable to exposure to all determined contaminants (i) through a single exposure pathway of the ingestion, and dermal contact of water $\left(\mathrm{HI}_{\text {Ingw }}\right.$ and $\left.\mathrm{HI}_{\text {Dermw }}\right)$ and sediment $\left(\mathrm{HI}_{\text {Ings }}\right.$ and $\mathrm{HI}_{\text {Derms }}$ ) was given as follows [60]:

$$
\begin{aligned}
\mathrm{HI}_{\text {IngW }} & =\sum \mathrm{HQ}\left(\text { Ing }_{\mathrm{W}}\right)_{i}, \\
\mathrm{HI}_{\text {DermW }} & =\sum \mathrm{HQ}\left(\text { Derm }_{\mathrm{W}}\right)_{i}, \\
\mathrm{HI}_{\text {IngS }} & =\sum \mathrm{HQ}\left(\text { Ing }_{\mathrm{S}}\right)_{i}, \\
\mathrm{HI}_{\text {DermS }} & =\sum \mathrm{HQ}\left(\text { Derm }_{\mathrm{S}}\right)_{i},
\end{aligned}
$$

\section{Results and Discussion}

\subsection{Distribution of Halogens and Tested Variables in Surface Water}

3.1.1. Distribution of Halogens in Surface Water. The range and average value of halogens in the surface water in this study show a sequence of $\mathrm{Cl}_{\mathrm{w}}>\mathrm{Br}_{\mathrm{w}}>\mathrm{F}_{\mathrm{w}}>\mathrm{I}_{\mathrm{w}}$ (Table 2 and Figure 2). The current study indicate that the water sample of pumping station (site 6) attained high concentrations of fluoride $\left(2.8 \mathrm{mg} \mathrm{L}^{-1}\right)$, chloride $\left(3887.8 \mathrm{mg} \mathrm{L}^{-1}\right)$, and bromide $\left(18.1 \mathrm{mg} \mathrm{L}^{-1}\right)$, and low iodide $\left(6.41 \mu \mathrm{g} \mathrm{L}^{-1}\right)$ contents (Figure 2). High levels of $\mathrm{F}, \mathrm{Br}$, and I are detected in the Main Basin region which is affected by the drainage of El-Qalaa and El Umoum containing the agricultural and industrial wastes. However, halogens are involved in the manufacture of pesticides (herbicides, fungicides, insecticides/acaricides, and nematicides) [67]. Plus, halogens are produced in the production of fertilizers products [67]. The presented results of halogens in the studied lake region reflect anomalous distribution and are mainly affected by water discharged from the drainage sources. However, the highest fluoride, bromide, and iodide contents of $3.77 \mathrm{mg} \mathrm{L}^{-1}, 65.53 \mathrm{mg} \mathrm{L}^{-1}$, and $54.10 \mu \mathrm{g} \mathrm{L}^{-1}$, respectively, are recorded in the Main Basin affected by El-Qalaa and El Umoum drains. Among the halogens, chloride shows high levels in surface water especially in site $1\left(7283.7 \mathrm{mg} \mathrm{L}^{-1}\right)$, site $2\left(6521.8 \mathrm{mg} \mathrm{L}^{-1}\right)$, and site $10\left(5168.7 \mathrm{mg} \mathrm{L}^{-1}\right)$ which are also related to their levels in the water of the drains (Figure 2). On the meantime, the lowest $\mathrm{S}_{\mathrm{o}_{\mathrm{w}}}$ and $\mathrm{Cl} \% \mathrm{o}_{\mathrm{w}}$ are observed at site 13 (El Umoum Drain). Most of the studied variables have chlorinity ratios relatively lower than those measured for Lake Mariout and/or seawater [51-53, 68, 69]. This is mainly due to the accumulation of wastewater from $\mathrm{Abis}$ and $\mathrm{El}$ Umoum, where agricultural products such as fertilizers and biocides are deposited in industrial products [19].

Due to the increase in chloride content in surface water samples, the conservativeness of the chlorinity ratio is used to describe the contamination, precipitation, and dissolution of sediment components [70]. The $\mathrm{F} / \mathrm{Cl}$ ratio in the study area is higher than open seawater $(4.30 E-05)$ of a range
$4.30 E-05-1.40 E-03$ and average $5.40 E-04$. The $\mathrm{Br} / \mathrm{Cl}$ ratio is relatively similar to that of seawater (Table 2). The highest $\mathrm{F} / \mathrm{Cl}, \mathrm{Br} / \mathrm{Cl}$, and $\mathrm{I} / \mathrm{Cl}$ ratios in surface water $1.40 E-03,1.60 E-02$, and $1.60 E-02$ are recorded in site 13 (El Umoum drain outside the lake), site 9 (South West Basin in the lake), and site 4 (Main Basin in the lake). Therefore, it can be concluded that the distribution of halogens in the surveyed area is greatly affected by the drainage of the ElQalaa, El Umoum, and the El Nubaria drains.

\subsubsection{Distribution of Tested Variables in Surface Water.} The range and average values of the tested variables $\left(\mathrm{T}_{\mathrm{w}}, \mathrm{S}\right.$ $\% o_{w}, \mathrm{Cl}_{0_{\mathrm{w}}}, \mathrm{TDS}_{\mathrm{w}}$, turbidity, $\mathrm{DO}_{\mathrm{w}}, \mathrm{pH}_{\mathrm{w}}, \mathrm{CO}_{3 \mathrm{w}}, \mathrm{HCO}_{3 \mathrm{w}}, \mathrm{B}_{\mathrm{w}}$, $\mathrm{P}_{\mathrm{w}}, \mathrm{Si}_{\mathrm{w}}, \mathrm{Ca}_{\mathrm{w}}, \mathrm{Mg}_{\mathrm{w}}, \mathrm{Na}_{\mathrm{w}}, \mathrm{K}_{\mathrm{w}}, \mathrm{Li}_{\mathrm{w}}, \mathrm{SO}_{4 \mathrm{w}}, \mathrm{Cu}_{\mathrm{w}}, \mathrm{Mn}_{\mathrm{w}}, \mathrm{Fe}_{\mathrm{w}}$, and $\mathrm{Zn}_{\mathrm{w}}$ ) in surface waters of the present study are listed in Table 2. Turbidity fluctuates from 1.66 to 38.50 NTU at sites 8 and 12 , respectively. DO is completely depleted at sites 5,6 , and 11 and has the highest amount $12.41 \mathrm{mg} \mathrm{L}^{-1}$ at site 2, with an average $6.05 \mathrm{mg} \mathrm{L}^{-1}$ relatively similar to the reported Lake Mariout value (2.14-5.63 $\mathrm{mg} \mathrm{L}^{-1}$; [54]) (Table 2). The average content of DO in the lake is higher than those reported for the ocean seawater (3.2-4.8 mg/L) [71]. The levels of DO probably relate to the oxygen-producing processes of the photosynthesis processes of phytoplankton and macrophytes [72]. The presented results indicate that site 1 (affect by Abis drainage) is the most affected area in the lake as it shows the highest contents of $\mathrm{B}_{\mathrm{w}}, \mathrm{Cl}_{\mathrm{w}}, \mathrm{Mg}_{\mathrm{w}}, \mathrm{Na}_{\mathrm{w}}, \mathrm{K}_{\mathrm{w}}$, $\mathrm{Li}_{\mathrm{w}}$, and $\mathrm{SO}_{4 \mathrm{w}}$. The most important feature in the concentrations of heavy metals $\mathrm{Cu}_{\mathrm{w}}, \mathrm{Mn}_{\mathrm{w}}$, and $\mathrm{Zn}_{\mathrm{w}}$ in surface water is that they possess average values lower than those reported for the threshold guideline $\left(10,100\right.$, and $\left.50 \mu \mathrm{g} \mathrm{L}^{-1}\right)[73,74]$.

The present study clears out a descending trend in the surface water average concentrations of halogens and tested variables in the lake as follows: $\mathrm{TDS}_{\mathrm{w}}>\mathrm{Cl}_{\mathrm{w}}>\mathrm{Na}_{\mathrm{w}}>$ $\mathrm{Mg}_{\mathrm{w}}>\mathrm{Ca}_{\mathrm{w}}>\mathrm{SO}_{4 \mathrm{w}}>\mathrm{HCO}_{3 \mathrm{w}}>\mathrm{K}_{\mathrm{w}}>\mathrm{CO}_{3 \mathrm{w}}>\mathrm{B}_{\mathrm{w}}>\mathrm{Br}_{\mathrm{w}}>\mathrm{F}_{\mathrm{w}}>$ Liw $>\mathrm{Zn}_{\mathrm{w}}>\mathrm{Fe}_{\mathrm{w}} \approx \mathrm{Si}_{\mathrm{w}}>\mathrm{Mn}_{\mathrm{w}}>\mathrm{P}_{\mathrm{w}}>\mathrm{I}_{\mathrm{w}}$ (Table 2).

3.1.3. Interactions of Halogens and Tested Variables in Surface Water. Chloride in surface water is significantly related to the drainage water content showing good correlations with $\mathrm{T}_{\mathrm{w}}(r=0.631, p \leq 0.028)$ and $\mathrm{pH}_{\mathrm{w}}(r=0.769$, $p \leq 0.003$ ) (Supplementary Table 1 ). The negative moderate relation of $\mathrm{F}_{\mathrm{w}}$ and $\mathrm{I}_{\mathrm{p}}(r=0.606, p \leq 0.037)$ may indicate replacement of iodine in pore water by fluoride of the surface water. The moderate relationship between fluoride in surface water and $\mathrm{CO}_{3 \mathrm{w}}(r=-0.632, p \leq 0.027)$ and $\mathrm{HCO}_{3 \mathrm{w}}$ $(r=0.593, p \leq 0.042)$ may be related to carbonate exchange and the formation of fluorite minerals $\left(\mathrm{CaF}_{2}\right)$ [23].

The correlation matrix reflects that the observed extraordinary levels of $B_{w}$ in the surface water samples are most probably due to its exchange with the different sediment components not related to the discharged waters (Supplementary Table 1). This findings is supported by the weak B correlation with $\mathrm{Cu}_{\mathrm{w}}(r=-0.587, p \leq 0.045)$ and good correlation with $\mathrm{F}_{\mathrm{s}}(r=-0.666, p \leq 0.018)[75,76]$. However, $\mathrm{Cu}_{\mathrm{w}}$ is one of the pollutants that can be exchanged in drainage water. The correlations of $\mathrm{Mg}_{\mathrm{w}} \& \mathrm{Na}_{\mathrm{w}}(r=0.629$, 


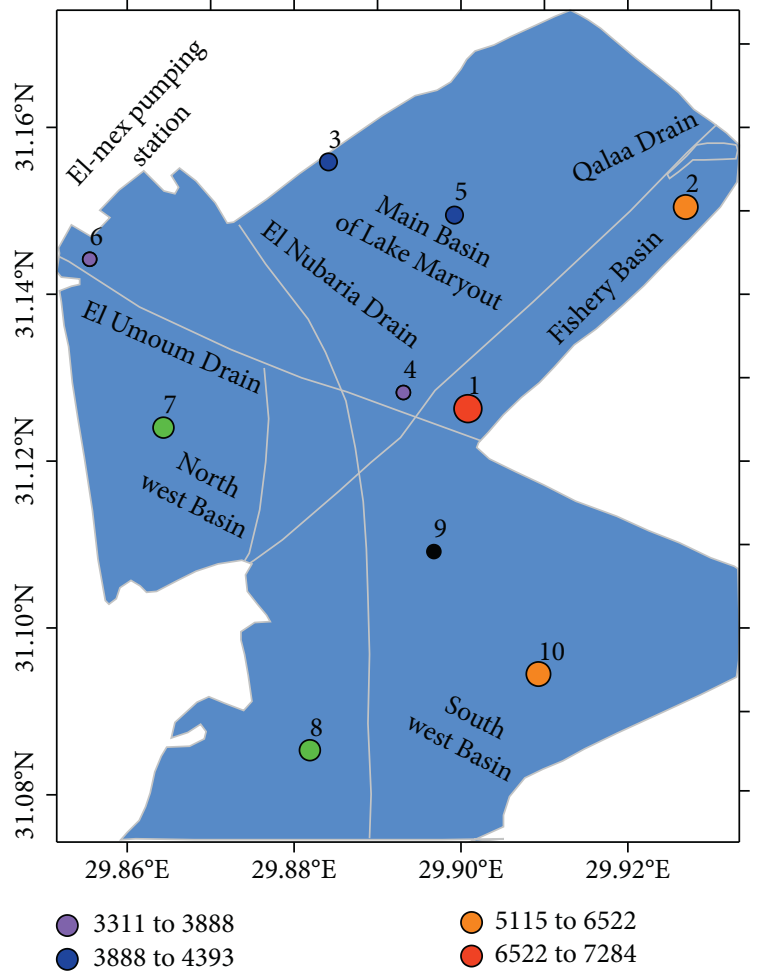

(a)

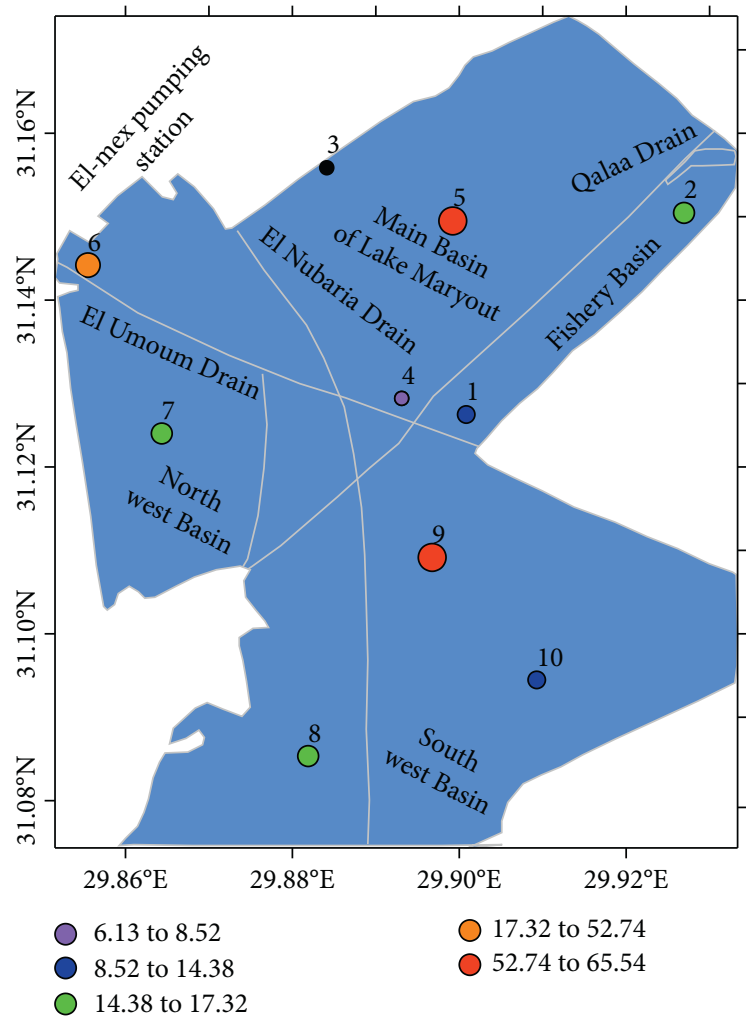

(c)

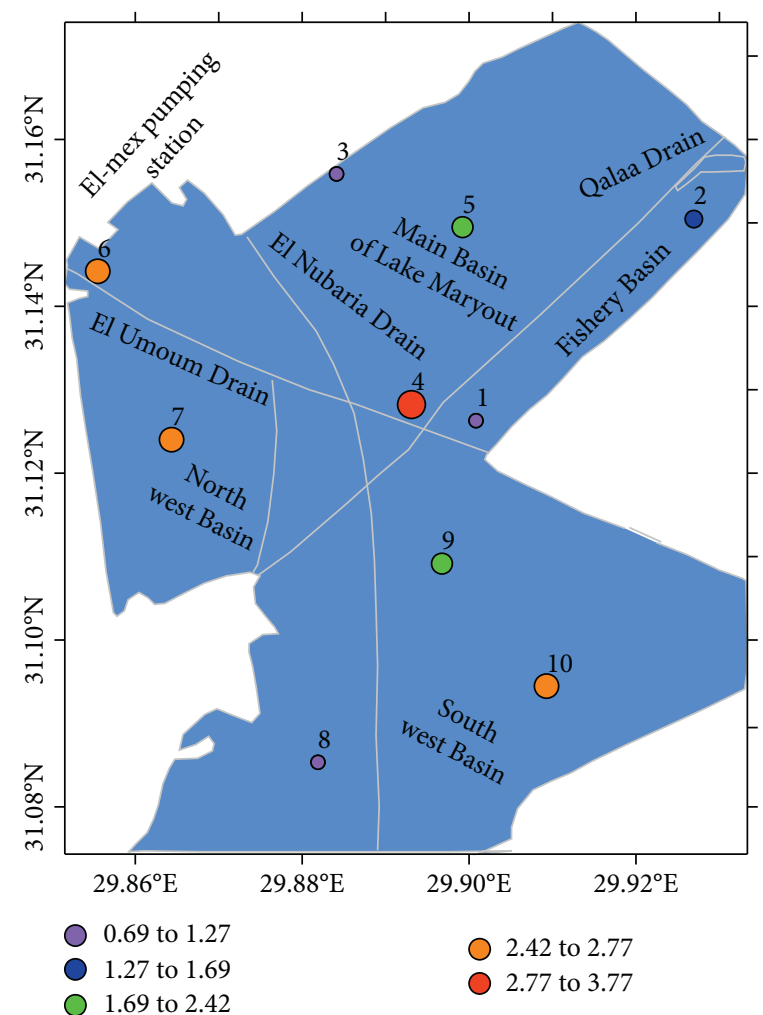

(b)

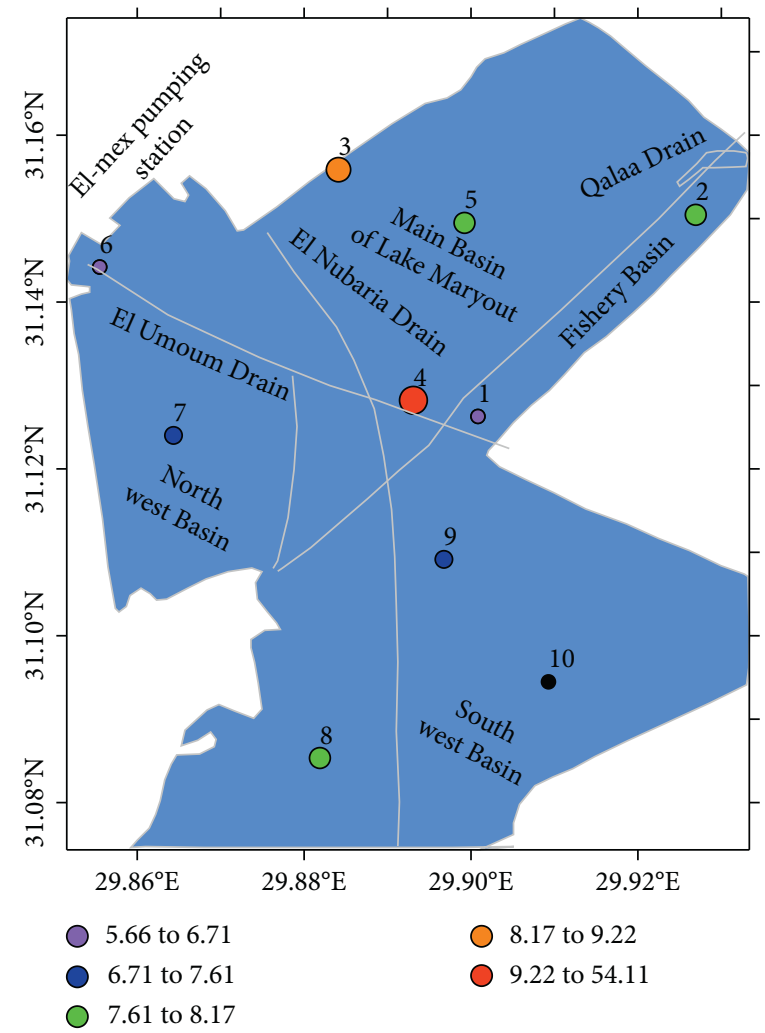

(d)

FigURE 2: Distribution of halogens ( $\mathrm{Cl}, \mathrm{F}, \mathrm{Br}$, and I in surface water of Lake Mariout, (a) $\mathrm{Cl}\left(\mathrm{mg} \mathrm{L}^{-1}\right)$, (b) $\mathrm{F}\left(\mathrm{mg} \mathrm{L}^{-1}\right),(\mathrm{c}) \mathrm{Br}\left(\mathrm{mg} \mathrm{L}^{-1}\right)$, and (d) I $\left.(\mu \mathrm{g} \mathrm{L})^{-1}\right)$. 
$p \leq 0.028), \mathrm{Mg}_{\mathrm{w}} \& \mathrm{Li}_{\mathrm{w}}(r=0.790, p \leq 0.002), \mathrm{Na}_{\mathrm{w}} \& \mathrm{~K}_{\mathrm{w}}$ $\left(r=0.955, p \leq 0.000, \mathrm{Na}_{\mathrm{w}} \& \mathrm{Li}_{\mathrm{W}}(r=0.835, p \leq 0.001), \mathrm{Na}_{\mathrm{w}} \&\right.$ $\mathrm{CO}_{3 \mathrm{w}}(r=-0.701, p \leq 0.011), \mathrm{K}_{\mathrm{w}} \& \mathrm{Li}_{\mathrm{w}}(r=0.712, p \leq 0.009)$, $\mathrm{K}_{\mathrm{w}} \& \mathrm{CO}_{3 \mathrm{w}}(r=-0.580, p \leq 0.048), \mathrm{CO}_{3 \mathrm{w}} \& \mathrm{HCO}_{3 \mathrm{w}}$ $(r=-0.613, \quad p \leq 0.034)$, and $\mathrm{Mg}_{\mathrm{w}} \& \mathrm{SO}_{4 \mathrm{w}} \quad(r=0.631$, $p \leq 0.028)$ indicate that all these variables have some geochemical behaviors [77]. $\mathrm{Mg}, \mathrm{Na}$, and $\mathrm{Li}$ are some components of the discharged waters; however, they have positive correlations with the chlorinity and salinity of the discharged water sources $(r=0.743,0.619$, and 0.815 , respectively) and ( $r=0.743,0.619$, and 0.815 , respectively). $\mathrm{Mg}_{\mathrm{w}}$ and $\mathrm{Li}_{\mathrm{w}}$ contents in water samples are affected by temperature, dissolved oxygen, and $\mathrm{pH}$ with high correlations of $r=-0.650,0.677$, and 0.743 , and $-0.702,0.659$, and 0.815 , respectively.

\subsection{Distribution of Halogens and Tested Variables in Pore Water}

3.2.1. Distribution of Halogens in Pore Water. The average halogen contents in the pore water are higher than their contents in the surface water, but in the same order $\mathrm{Cl}_{\mathrm{p}}>\mathrm{B}_{\mathrm{p}}>\mathrm{F}_{\mathrm{p}}>\mathrm{I}_{\mathrm{p}}$ (Table 3). Current research shows that the lowest and highest average values of $S \%{ }_{p}$ and $\mathrm{Cl}_{\mathrm{p}}$ have been measured in the pore water of site 6 and site 8 , respectively. It is worth mentioning that site 6 is a mixed water of El-Qalaa drainage, sewage WWTP treatment plant, and lake water. Interestingly, the high concentrations of fluoride, chloride, bromide, and iodide in the pore water at site 6 are $12.3 \mathrm{mg}$ $\mathrm{L}^{-1}, 4032.1 \mathrm{mg} \mathrm{L}^{-1}, 117.39 \mathrm{mg} \mathrm{L}^{-1}$, and $243.39 \mu \mathrm{g} \mathrm{L}^{-1}$, respectively (Table 3 ). The salinity and chloride content in the pore water of site 8 are related to the discharge water of many petrochemical and oil companies besides some fish farms.

3.2.2. Distribution of Tested Variables in Pore Water. The tested variables in the pore water $(\mathrm{p})$ give the following descending order: $\mathrm{Mg}_{\mathrm{p}}>\mathrm{Na}_{\mathrm{p}}>\mathrm{Ca}_{\mathrm{p}}>\mathrm{SO}_{4 \mathrm{p}}>\mathrm{B}_{\mathrm{p}}>\mathrm{K}_{\mathrm{p}}>\mathrm{Br}_{\mathrm{p}}$ $>\mathrm{F}_{\mathrm{p}}>\mathrm{Li}_{\mathrm{p}}>\mathrm{P}_{\mathrm{p}}>\mathrm{I}_{\mathrm{p}}>\mathrm{Si}_{\mathrm{p}}$ (Table 3). Interestingly, the determined variables in the pore water have higher values than the surface water along the lake. According to previous studies, pore water is responsible for biogeochemical reactions, the migration and transformation of partitioned and formed compounds, and the transportation of colloidal species $[78,79]$. In addition, pore water can explore the potential risks of man-made pollution sources [80]. The tested variables in the pore water $(\mathrm{p})$ are given in a different order of surface water of $\mathrm{Cl}_{\mathrm{p}}>\mathrm{Mg}_{\mathrm{p}}>\mathrm{Na}_{\mathrm{p}}>\mathrm{Ca}_{\mathrm{p}}$ $>\mathrm{SO}_{4 \mathrm{p}}>\mathrm{B}_{\mathrm{p}}>\mathrm{K}_{\mathrm{p}}>\mathrm{Br}_{\mathrm{p}}>\mathrm{F}_{\mathrm{p}}>\mathrm{Li}_{\mathrm{p}}>\mathrm{P}_{\mathrm{p}}>\mathrm{I}_{\mathrm{p}}>\mathrm{Si}_{\mathrm{p}} \quad$ (Tables 2 and 3 ).

3.2.3. Interactions of Halogens and Tested Variables in Pore Water. The following interactions of halogens $\mathrm{CO}_{3 \mathrm{w}} \& \mathrm{I}_{\mathrm{p}}, \mathrm{I}_{\mathrm{p}}$ $\& \mathrm{~F}_{\mathrm{w}}, \mathrm{Br}_{\mathrm{w}} \& \mathrm{Si}_{\mathrm{p}}, \mathrm{F}_{\mathrm{p}} \& \mathrm{Si}_{\mathrm{w}}$, and $\mathrm{F}_{\mathrm{p}} \& \mathrm{Na}_{\mathrm{p}}$ give correlation values $(r=0.706, p \leq 0.010, r=-0.606, p \leq 0.037, r=0.826$, $p \leq 0.001, r=-0.704, p \leq 0.011$, and $r=0.670, p \leq 0.017$, respectively) (Supplementary Table 1). However, these relationships may indicate their precipitation and/or adsorption on the colloidal particles besides the formation of some chemical species [78, 79]. Extraordinarily large correlations of $\mathrm{Na}_{\mathrm{p}} \& \mathrm{HCO}_{3 \mathrm{w}}, \mathrm{K}_{\mathrm{p}} \& \mathrm{HCO}_{3 \mathrm{w}}, \mathrm{S} \% \mathrm{o}_{\mathrm{w}} \& \mathrm{~B}_{\mathrm{p}}, \mathrm{S} \% \mathrm{o}_{\mathrm{p}}$ \& $\mathrm{K}_{\mathrm{p}}, \mathrm{S} \%$ op \& $\mathrm{Li}_{\mathrm{p}}$, and $\mathrm{S} \% o_{\mathrm{p}} \& \mathrm{Cl}_{\mathrm{p}}(r=0.692,-0.609,-0.741$, $0.696,0.910$, and 1.000) may refer to the release of these elements from sediment particles and/or precipitation or adsorption [77]. In the matrix, the negative correlation between $\mathrm{Ca}_{\mathrm{p}}$ and $\mathrm{Mg}_{\mathrm{p}}(r=-0.592, p \leq 0.042)$ may be related to the release of $\mathrm{Mg}$ during the recrystallization of calcite [79]. The relationship between $\mathrm{Ca}_{\mathrm{w}} \& \mathrm{SO}_{4 \mathrm{p}}, \mathrm{Cu}_{\mathrm{w}} \& \mathrm{Ca}_{\mathrm{p}}, \mathrm{P}_{\mathrm{w}} \&$ $\mathrm{P}_{\mathrm{p}}$, and $\mathrm{Na}_{\mathrm{p}} \& \mathrm{pH}_{\mathrm{w}}(r=0.744, p \leq 0.006 ; r=0.719, p \leq 0.008$; $r=0.647, p \leq 0.023$; and $r=-0.640, p \leq 0.025$, respectively) may be due to the chemical interactions in the pore fluids and the formation certain compounds.

\subsection{Distribution of Halogens and Tested Variables in Sediment}

3.3.1. Distribution of Halogens in Sediment. The average halogen's content in the sediment shows a different order from the surface and pore waters of $\mathrm{Br}_{\mathrm{s}}>\mathrm{F}_{\mathrm{s}}>\mathrm{Cl}_{\mathrm{s}}>\mathrm{I}_{\mathrm{s}}$ (Table 4). The sediment results show that the average bromide content is higher than fluoride, followed by chloride content and iodide with average values of $4.52 \mathrm{mg} \mathrm{g}^{-1}, 0.40 \mathrm{mg} \mathrm{g}^{-1}$, $0.29 \mathrm{mg} \mathrm{g}^{-1}$, and $4.50 \mu \mathrm{g} \mathrm{g}^{-1}$, respectively.

The fluoride concentration in the sediment ranges from 0.01 to $1.20 \mathrm{mg} \mathrm{g}^{-1}$, with an average value of $0.4 \pm 0.35 \mathrm{mg}$ $\mathrm{g}^{-1}$. These values are lower than reported marine sediment values and higher than the El-Bardawil Lagoon [60]. Amongst the halogens, the study reveals that $\mathrm{Br}$ is the most abundant ion in surface water, pore water, and sediment samples due to the excessive amounts of organic matter [81]. On the contrary, the concentration of $\mathrm{Cl}$ ions in sediment samples is lower than that in surface water and pore water samples, indicating that it exists in soluble salts. The current results indicate that the sediments collected from the most affected area by the Mediterranean Sea (site 6) contain elevated levels of fluoride $\left(0.70 \mathrm{mg} \mathrm{g}^{-1}\right)$, bromide $(8.52 \mathrm{mg}$ $\left.\mathrm{g}^{-1}\right)$, and chloride $\left(0.20 \mathrm{mg} \mathrm{g}^{-1}\right)$ and a reduced amount of iodide $\left(2.09 \mu \mathrm{g} \mathrm{g}^{-1}\right)$ (Table 4).

3.3.2. Distribution of Tested Variables in Sediment. The average value of test variables in the determined sediment samples shows a significant change from site to site, with a descending order $\mathrm{CO}_{3 \mathrm{~s}}>\mathrm{Mg}_{\mathrm{s}}>\mathrm{Ca}_{\mathrm{s}}>\mathrm{Na}_{\mathrm{s}}>\mathrm{SO}_{4 \mathrm{~s}}>\mathrm{Fe}_{\mathrm{s}}>\mathrm{B}_{\mathrm{s}}>$ $\mathrm{K}_{\mathrm{s}}>\mathrm{TP}_{\mathrm{s}}>\mathrm{Mn}_{\mathrm{s}}>\mathrm{Zn}_{\mathrm{s}}>\mathrm{Cu}_{\mathrm{s}}>\mathrm{Li}_{\mathrm{s}}$ (Table 4). Plus, this study clears out that the percent of sand and mud of the different sediment samples ranges from $4 \%$ at sites $1 \& 13$ to $85 \%$ at site 11 and from $15 \%$ at site 11 to $96 \%$ at sites $1 \& 13$, respectively, with averages $25 \%$ and $75 \%$, respectively. Plus, the porosity $\%$ shows a trend opposite to the particle size and varies from 46.76 to 82.14 , with an average value of $56.09 \pm 11.14$. The results of the current study reveal moderate amounts of $\% \mathrm{CO}_{3}$ in the sediment samples fluctuating between 16.39 and 57.36 at sites 6 and 2, respectively. The results of sand, mud, porosity, and $\mathrm{CO}_{3}$ percentage reflect that the texture of the sediment is mainly composed of mud mixed with carbonate compounds. Comprehensively, the large storage of sediments with carbonate $(35.9 \pm 12.80 \%)$, magnesium 


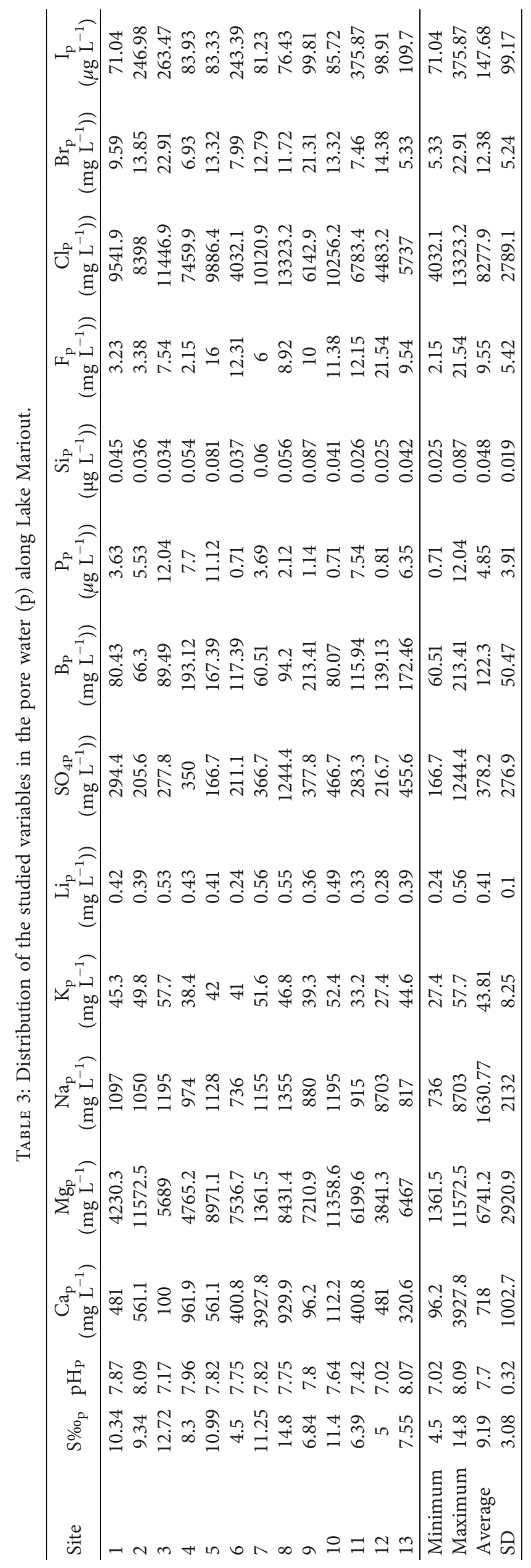




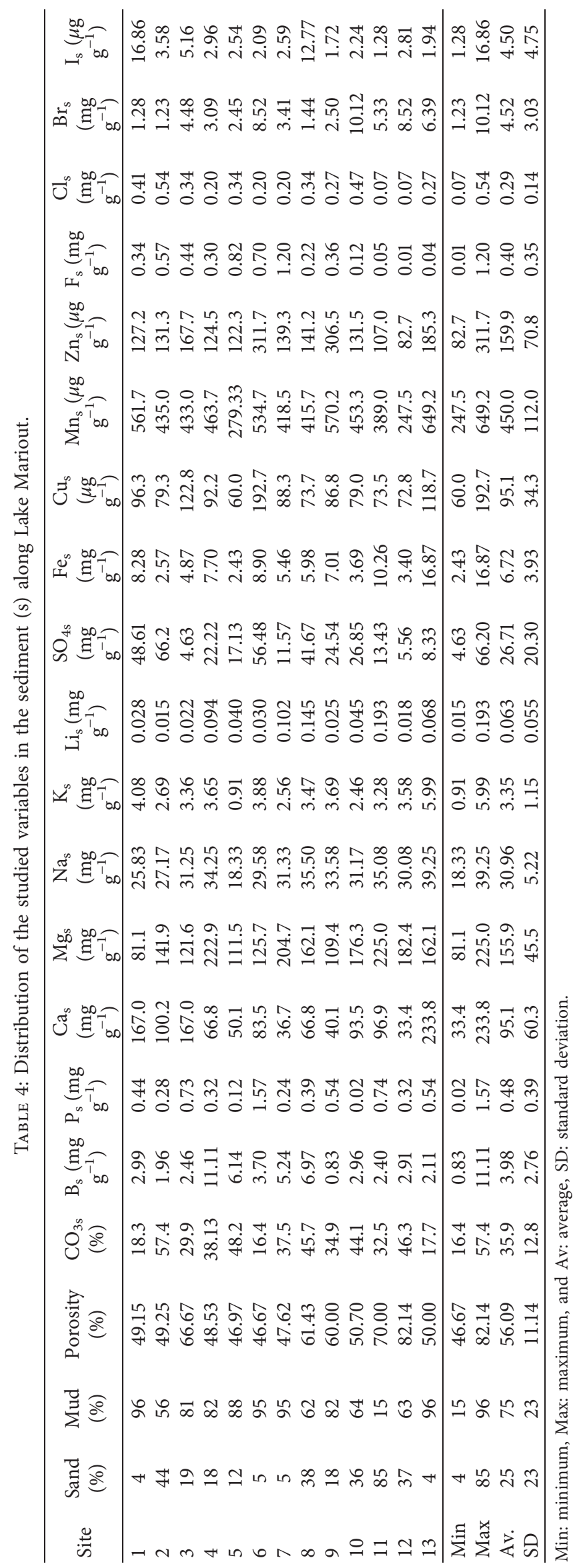


$\left(155.9 \pm 45.5 \mathrm{mg} \mathrm{g}^{-1}\right)$, and calcium $\left(95.1 \pm 60.3 \mathrm{mg} \mathrm{g}^{-1}\right)$ components may be attributed to the abundance of calcium minerals [4]. However, in general, the average amounts of all variables in sediment samples show marked variations from one site to another with a descending order of $\mathrm{CO}_{3 \mathrm{~s}}>$ $\mathrm{Mg}_{\mathrm{s}}>\mathrm{Ca}_{\mathrm{s}}>\mathrm{Na}_{\mathrm{s}}>\mathrm{SO}_{4 \mathrm{~s}}>\mathrm{Fe}_{\mathrm{s}}>\mathrm{Br}_{\mathrm{s}}>\mathrm{B}_{\mathrm{s}}>\mathrm{K}_{\mathrm{s}}>\mathrm{TP}_{\mathrm{s}}>\mathrm{F}_{\mathrm{s}}>\mathrm{Cl}_{\mathrm{s}}>$ $\mathrm{Mn}_{\mathrm{s}}>\mathrm{Zn}_{\mathrm{s}}>\mathrm{Cu}_{\mathrm{s}}>\mathrm{Li}_{\mathrm{s}}>\mathrm{I}_{\mathrm{s}}$ (Table 4). The measured concentrations of $\mathrm{Mn}, \mathrm{Zn}, \mathrm{Cu}$, and $\mathrm{Fe}$ in the sediment samples are still lower than the reported values and also lower than the background levels of crust and the toxicological reference contents of US DOE (U.S. Department of Energy), US EPA (U.S. Environmental Protection Agency), and CEQG (Canadian Environmental Quality Guidelines) [82].

Contrasting the obtained levels for the halogens with those previously reported ones, the present study indicates that surface and pore waters incorporate more considerable amounts of fluoride compared to the formerly reported ones in Lake Edku (Tables 2 and 3) and lower levels in the Mariout area than those measured along the Egyptian Mediterranean Sea coast [27]. Compared with the sediments previously found on the Mediterranean coast of Egypt, the chloride content in the sediments of the Mariout area is lower [83]. Compared with those observed in seawater, the studied surface water and pore water samples have lower bromide content and higher levels than previously reported in Lake Mariout [52, 53]. The concentration of iodide in surface water, pore water, and sediments is equivalent to the concentration of rivers and lakes in the world [84].

3.3.3. Interactions of Halogens and Tested Variables in Sediment. The correlation matrix shows the important role of halogens in the formation and precipitation/dissolution of salts and minerals produced along the lake (Supplementary Table 1). However, it shows that chloride seems to be in the soluble forms along the surface and pore waters of studied area showing good relations with $\mathrm{Ca}_{\mathrm{w}}(r=0.666, p \leq 0.018)$, $\mathrm{Cl}_{\mathrm{p}}(r=0.677, p \leq 0.016)$, and $\mathrm{SO}_{4 \mathrm{p}}(r=0.858, p \leq 0.000)$. Also, $\mathrm{Cl}_{\mathrm{s}}$ gives good correlations with $\mathrm{Mg}_{\mathrm{w}}(r=0.710$, $p \leq 0.010), \quad \mathrm{Na}_{\mathrm{w}} \quad(r=0.602, \quad p \leq 0.038), \quad \mathrm{Cl}_{\mathrm{w}} \quad(r=0.619$, $p \leq 0.032), \mathrm{Mg}_{\mathrm{p}}(r=0.774, p \leq 0.003)$, and $\mathrm{K}_{\mathrm{p}}(r=0.731$, $p \leq 0.007)$. Chloride in the surface and pore waters plays an important role in the dissolution, association, and formation of various salts along the lake. The good relationship between $\mathrm{I}_{\mathrm{s}}$ and $\mathrm{Ca}_{\mathrm{w}}(r=0.666, p \leq 0.018)$ may reflect the deposition/release of $\mathrm{CaI}^{+}$during the formation/dissolution of calcium carbonate [85]. In addition, these correlations may be related to organic-I which formed by bacterial species and their remineralization in bottom sediments [86]. The moderate relationship between $\mathrm{Na}_{\mathrm{s}}$ and $\mathrm{Br}_{\mathrm{w}}(r=-0.622$, $p \leq 0.031)$ may indicate the possible formation of $\mathrm{BrCl}$ species and the precipitation or adsorption of $\mathrm{Na}$ minerals in sediments [87]. The results of this study also reflect the strong negative correlation between $\mathrm{F}_{\mathrm{s}}$ and $\mathrm{B}_{\mathrm{w}}(r=-0.666$, $p \leq 0.018$ ) which may be related to the release of fluoride from sediment and the formation of soluble fluoride complexes $\left(\left(\mathrm{BF}_{\mathrm{n}}[\mathrm{OH}]_{4-n}\right)^{-}\right)$with the excessive boron concentration in the water [88]. The negative relation between $\mathrm{K}_{\mathrm{s}}$ and $\mathrm{S} \% 0_{\mathrm{W}}(r=-0.673, p \leq 0.016)$ possibly reflect that $\mathrm{K}_{\mathrm{W}}$ preferentially chooses to exist in the soluble form of $\mathrm{KCl}$, rather than being adsorbed and/or bound by some rich minerals in the sediment.

The significant correlations between $\mathrm{CO}_{3 \mathrm{~s}}$ and $\mathrm{Mg}_{\mathrm{w}}$ $(r=0.637, p \leq 0.026), \mathrm{CO}_{3 \mathrm{~s}}$ and $\mathrm{Cl}_{\mathrm{W}}(r=0.723, p \leq 0.008)$, $\mathrm{CO}_{3 \mathrm{~s}}$ and $\mathrm{pH}_{\mathrm{w}}(r=0.833, p \leq 0.001), \mathrm{CO}_{3 \mathrm{~s}}$ and $\mathrm{S} \% 0_{\mathrm{w}}$ $(r=0.723, p \leq 0.008)$, and between $\mathrm{CO}_{3 \mathrm{~s}}$ and $\mathrm{K}_{\mathrm{s}}(r=-0.673$, $p \leq 0.016$ ) may be accompanied by the possible formation/ dissolution of the dolomite mineral in the presence of sufficient $\mathrm{Mg}_{\mathrm{w}}$, which is usually affected by optimal $\mathrm{pH}$, salinity, and the potassium salts (Supplementary Table 1). These observed results are matching with the previously reported studies [32]. Significant negative correlation between $\mathrm{TP}_{\mathrm{s}}$ and $\mathrm{CO}_{3 \mathrm{~s}}(r=-0.744, p \leq 0.006)$ may indicate the extended release of $\mathrm{P}$ from carbonate minerals and formation of apatites [32].

The correlation matrix also refers to other possible interactions between the remaining determined variables (Supplementary Table 1). The significant correlation between $\mathrm{SO}_{4 \mathrm{~s}}$ and $\mathrm{Mg}_{\mathrm{w}}(r=0.706, p \leq 0.010)$ and $\mathrm{Li}_{\mathrm{w}}(r=0.633$, $p \leq 0.027)$ may be associated to the formation of Mg-sulfate and the pollution of sediments by discharged waters containing excessive sulfate and $\mathrm{Li}$ [89]. In the contrary, the strong positive correlation between $\mathrm{TP}_{s}$ and $\mathrm{Cu}_{s}$ and between TPs and $\mathrm{Zn}_{\mathrm{s}}$ may be related to the same source of polluted discharge water $[23,83]$.

The high negative correlations of $\mathrm{Zn}_{\mathrm{s}}$ with $\mathrm{Fe}_{\mathrm{w}}$ $(r=-0.785, p \leq 0.003), \mathrm{CO}_{3 \mathrm{~s}}(r=-0.601, p \leq 0.039)$, and $\mathrm{Cu}_{\mathrm{s}}$ $(r=0.698, p \leq 0.012)$ may indicate that $\mathrm{Zn}, \mathrm{Cu}$, and $\mathrm{CO}_{3}$ depositions in sediment samples are linked to the soluble $\mathrm{Fe}$ form in water (ferrous), i.e., the release of Fe upwards in the water column in the anoxic conditions (Supplementary Table 1) [90]. The excellent relations found between $\mathrm{Fe}_{s}$ and $\mathrm{CO}_{3 \mathrm{~s}}(r=-0.799, p \leq 0.002), \mathrm{Fe}_{\mathrm{s}}$ and $\mathrm{Ca}_{\mathrm{s}}(r=0.637$, $p \leq 0.026), \mathrm{Fe}_{\mathrm{s}}$ and $\mathrm{Cl}_{\mathrm{w}}(r=-0.752, p \leq 0.005), \mathrm{Fe}_{\mathrm{s}}$ and $\mathrm{Na}_{\mathrm{s}}$ $(r=0.720, p \leq 0.008)$, and between $\mathrm{Fe}_{\mathrm{s}}$ and $\mathrm{K}_{\mathrm{s}}(r=0.833$, $p \leq 0.001)$ may reflect the dissolution of the chelating $\mathrm{Fe}$ association with the soluble organic compounds in the water-sediment interface, and the formation of the soluble ferrous form in low dissolved oxygen within the areas affected by untreated discharged waters [90]. The strong correlations of $\mathrm{Mn}_{\mathrm{s}}$ with $\mathrm{SO}_{4 \mathrm{w}}, \mathrm{Na}_{\mathrm{p}}, \mathrm{Na}_{\mathrm{s}}, \mathrm{K}_{\mathrm{s}}, \mathrm{CO}_{3 \mathrm{~s}}$, $\mathrm{Zn}_{\mathrm{s}}$, and $\mathrm{Fe}_{\mathrm{s}}(r=-0.585,0.608,0.611,0.698,-0.655,0.691$, and 0.716 , respectively) may associate with the solubility of abundant Mn minerals and P-Mn forms in the sediment because of its possible reduction to $\mathrm{Mn}^{+2}$ soluble species under anoxic conditions [90]. It is worth mentioning that the results of this study indicate that approximately $33.3 \%$ of the survey sites indicate the depletion of dissolved oxygen in their surface water samples. Under such anoxic conditions, bacteria are most likely to use sulfate instead of oxygen to break down organic matter and cause the release of iron and phosphorus into the water column.

The significant direct correlation between $\mathrm{K}_{\mathrm{s}}$ and $\mathrm{Na}_{\mathrm{s}}$ $(r=0.832, p<0.001)$ clearly reflects the transport of soluble salts of $\mathrm{K}$ and $\mathrm{Na}$ between the pore water phase of the sediment and water-sediment surface phase (Supplementary Table 1). The good correlation between porosity and $\mathrm{Na}_{\mathrm{s}}$ 
indicates the possible transfer of $\mathrm{Na}$ between pore water and sediment partitions.

3.4. Interactions of Precipitated Halogenated Compounds in Surface and Pore Waters. The Saturation Index (SI) $[23,60]$ of twenty-three and fifteen structures in surface water and pore water samples, respectively, are listed (Table 1). The correlation matrix of the calculated Saturation Indices with the presented data shows the different factors affecting the interaction of the halogenated compound with other precipitated salts and minerals. Table 1 explores the precipitation of the phosphate minerals, and salts are most abundant followed by the hydroxides' salts, iodate salts, sulfate, and carbonate minerals and salts in surface waters. Amongst the halogens precipitated salts, fluoride minerals, especially, fluorapatites and carbonate-fluorapatite (FAP and CFAP), have high SI values in surface water (42.77-51.95 and $16.04-60.89$, respectively) and in pore water (51.26-54.60 and 17.52-78.33, respectively). Bromide and chloride are mainly found in the soluble forms in surface and pore waters. Iodide salts, $\left(\mathrm{Ca}\left(\mathrm{IO}_{3}\right)_{2}\right.$ and $\left.\mathrm{Ca}\left(\mathrm{IO}_{3}\right)_{2} \cdot 6 \mathrm{H}_{2} \mathrm{O}\right)$, moderately precipitate in surface and pore. Iron salts precipitate in surface water, while in pore water, they are not formed. Thus, SI content reflects that halogens, especially fluoride and iodide, play a vital role in reducing lake pollution.

In addition, Table 1 shows that the precipitation compounds that may be formed in surface water are relatively different from those in sediment pore water. For example, fluorite $\left(\mathrm{CaF}_{2}\right)$ and sellaite $\left(\mathrm{MgF}_{2}\right)$ may be only formed in pore water, while calcite and aragonite may be deposited in surface water. However, the formation of fluorite in surface water is related to $\mathrm{Na}_{\mathrm{w}}(r=0.778, p \leq 0.003), \mathrm{K}_{\mathrm{w}}(r=0.704$, $p \leq 0.011), \quad \mathrm{CO}_{3} \mathrm{~W} \quad(r=-0.718, p \leq 0.009), \quad \mathrm{F}_{\mathrm{w}} \quad(r=0.770$, $p \leq 0.003)$, and $\mathrm{I}_{\mathrm{p}}(r=-0.785, p \leq 0.003)$ (Supplementary Table 1).

The formation of calcium sulfate hemihydrate, calcium sulfate, and anhydrite in water is related to the increase in the amounts of $\mathrm{Ca}_{\mathrm{w}}, \mathrm{Mg}_{\mathrm{w}}, \mathrm{SO}_{4 \mathrm{w}}, \mathrm{Na}_{\mathrm{p}}, \mathrm{F}_{\mathrm{p}}, \mathrm{Si}_{\mathrm{p}}, \mathrm{Cl}_{\mathrm{s}}$, and $\mathrm{Mn}_{\mathrm{s}}$, and the decrease in porosity values. On the other hand, precipitation of calcium phosphate is related to $\mathrm{Br}_{\mathrm{w}}(r=0.751$, $p \leq 0.005), \quad \mathrm{Zn}_{\mathrm{w}} \quad(r=0.668, \quad p \leq 0.018), \quad \mathrm{P}_{\mathrm{w}} \quad(r=0.881$, $p \leq 0.001)$, and $\mathrm{K}_{\mathrm{s}}(r=0.881, p \leq 0.001)$; i.e., it is affected by the discharged water composition (Supplementary Table 1).

The formation of calcite and aragonite in surface water is related to the formation of $\mathrm{CO}_{3 \mathrm{~W}}(r=0.753, p \leq 0.005)$ and dissociation of $\mathrm{HCO}_{3 \mathrm{w}}(r=-0.660, p \leq 0.020), \mathrm{pH}_{\mathrm{w}}$ values $(r=-0.654, p \leq 0.021)$, and their dissolution in sediment $(r=-0.620, p \leq 0.032)$ (Supplementary Table 1).

The dolomite formation in water may be affected by the increase of $\mathrm{CO}_{3 \mathrm{~W}}(r=0.817, p \leq 0.001)$ and the decrease of $\mathrm{HCO}_{3 \mathrm{w}}(r=-0.658, p \leq 0.020)$, increase in $\mathrm{TDS}_{\mathrm{w}}(r=0.599$, $p \leq 0.040)$, and increase in $\mathrm{pH}_{\mathrm{w}}(r=-0.656, p \leq 0.021)$, besides the possible release of $\mathrm{CO}_{3 \mathrm{~s}}$ from abundant sediment $(r=-0.624, p \leq 0.030)$ and the precipitation of calcite $(r=0.984, p \leq 0.000)$ and aragonite $(r=0.984, p \leq 0.000)$ into sediment fraction (Supplementary Table 1).

Generally, in the current study, the possible formed halogenated minerals and salts are affected by their abundance in different components of the lake, besides their possible dissolution or formation on the sediment textures, geochemistry of the sediments, and physicochemical variables of water, in addition to the components of the discharged waters.

3.5. Interactions of Dissolved Halogenated Compounds in Surface and Pore Waters. The utilization of dissolved salts in surface and pore waters, by utilizing Palmer's method and piper ternary diagram [50], indicates that $\mathrm{Na}$ is the richest cation in surface water, followed by $\mathrm{Mg}, \mathrm{Ca}$, and $\mathrm{K}$. At the same time, $\mathrm{Mg}$ is the most predominate one in the pore water (Figures 3 and 4). Obviously, $\mathrm{Cl}$ is the most important anion in surface water and pore waters samples. However, the piper ternary diagrams of surface water and pore water clearly shows that $\mathrm{NaCl}$ is the most dominant in surface water, while $\mathrm{MgCl}_{2}$ is the most abundant in pore water. Coincidently, Palmer's method also reflects that $\mathrm{NaCl}$ $(57.4 \%)$ is the most existent species in surface water, followed by $\mathrm{MgCl}_{2}$ (30.4\%), $\mathrm{CaCl}_{2}$ (7.1\%), $\mathrm{CaSO}_{4}$ (2.9\%), $\mathrm{Ca}\left(\mathrm{HCO}_{3}\right)_{2}(1.4 \%)$, and $\mathrm{KCl}(1.2 \%)$ (Figure 3). At the same time, $\mathrm{MgCl}_{2}(76.0 \%)$ is the most present species in pore water, followed by $\mathrm{NaCl}(7.3 \%) \approx \mathrm{Mg}\left(\mathrm{HCO}_{3}\right)_{2} \quad$ (7.3\%), $\mathrm{Ca}\left(\mathrm{HCO}_{3}\right)_{2}(5.2 \%)$, and $\mathrm{MgSO}_{4}$ (3.1\%) (Figure 4).

\subsection{Multivariate Analysis}

3.6.1. Principal Component (PCA). By applying Varimax rotation and Kaiser normalization to 98 variables in the PCA for halogens and tested variables and calculated parameter values, 7 extracted PCs with eigenvalues higher than 1 are obtained. However, it is important that the eigenvalue must be greater than 1 . Its seven PCs explain $85.58 \%$ of the total variance.

The first principle component (PC1) is $14.73 \%$ of the total variance and shows positive coefficient factor loadings for $\mathrm{CO}_{3 \mathrm{w}}, \mathrm{TDS}_{\mathrm{w}}, \mathrm{K}$, calcite, aragonite, dolomite, $\mathrm{FeCO}_{3}$, $\mathrm{MgCO}_{3}, \mathrm{ZnCO}_{3}$, and $\mathrm{ZnCO}_{3} \cdot \mathrm{H}_{2} \mathrm{O}(0.804,0.547,0.532$, $0.938,0.938,0.947,0.741,0.940,0.866$, and 0.866 , respectively). In addition, it provides negative factor loadings for $\mathrm{HCO}_{3 \mathrm{w}}, \mathrm{pH}_{\mathrm{w}}, \mathrm{B}_{\mathrm{w}}, \mathrm{Na}_{\mathrm{p}}$, and $\mathrm{CO}_{3 \mathrm{~s}}(-0.782,-0.610,-0.595$, -0.532 , and -0.572 , respectively). PC1 is related to the factors affecting the carbonate compounds that may be formed in the area under consideration.

PC2 accounts to $14.58 \%$ of the total variance and also shows positive and negative coefficient factor loadings representing the different interactions between the $\mathrm{Ca}_{w}$, $\mathrm{Mg}_{\mathrm{w}}, \mathrm{Li}_{\mathrm{w}}, \mathrm{SO}_{4 \mathrm{w}}, \mathrm{Mg}_{\mathrm{p}}, \mathrm{Na}_{\mathrm{p}}, \mathrm{pH}_{\mathrm{p}}, \mathrm{Cl}_{\mathrm{s}}, \mathrm{SO}_{4 \mathrm{~s}}, \mathrm{Br}_{\mathrm{s}}$, and porosity\% in water, pore water, and sediment that are responsible for the composition of sulfate, magnesium, and phosphate precipitates besides the effect of the discharged waters on water-pore water-sediment components' cycles.

PC3 typically shows $13.77 \%$ of the total variance with positive and negative loadings which can properly explore the effect of the principal sources of local pollution on the dissolving of heavy metals, $\mathrm{B}$, and $\mathrm{P}$ from sediment into the water column and the probable formation of $\mathrm{Fe}(\mathrm{OH})_{2}$, $\left.\mathrm{Fe}(\mathrm{OH})_{3}\right)$, and $\mathrm{FePO}_{4}$. 


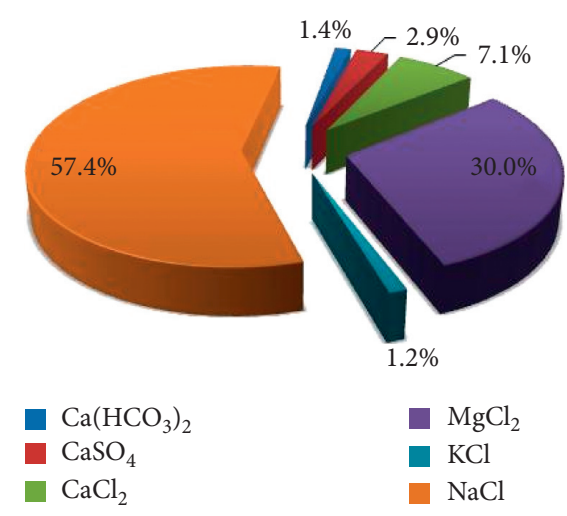

(a)

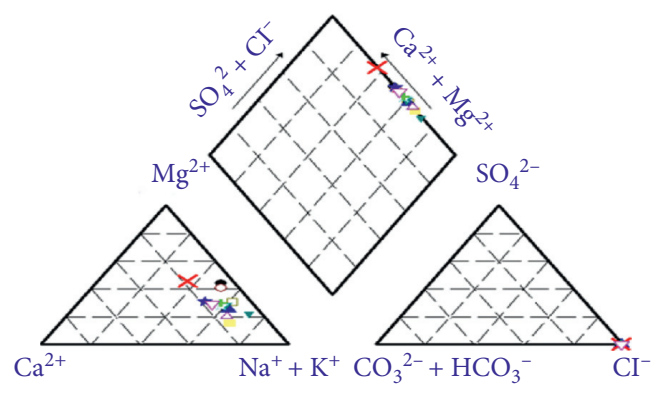

(b)

FIgURE 3: (a) \% distribution and (b) piper ternary diagram of the formed dissolved salts in surface water of Lake Mariout.

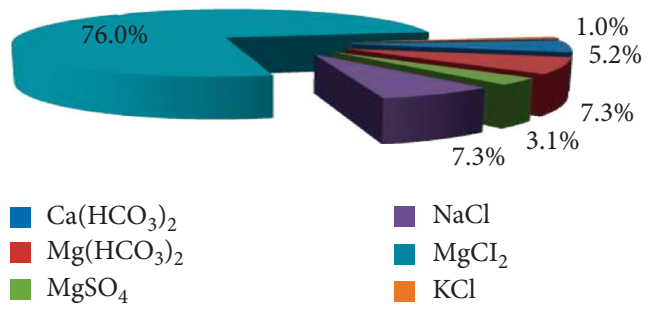

(a)

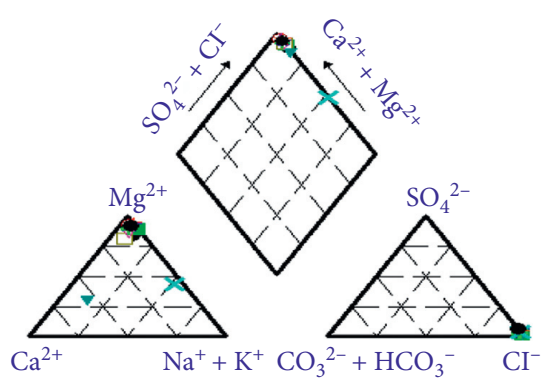

(b)

FiguRE 4: (a) \% distribution and (b) piper ternary diagram of the formed dissolved salts in pore water of Lake Mariout.

Similarly, the coefficient factor loadings of PC4 with $13.55 \%$ are related to the influence of the polluted discharge water and sediment texture on the formation of $\mathrm{F}, \mathrm{Cl}$, and I salt, besides the precipitation of halogenated compounds $\left(\mathrm{FeF}_{2}, \mathrm{Mn}\left(\mathrm{IO}_{3}\right)_{2}, \mathrm{KIO}_{4}\right.$, and $\left.\mathrm{KCIO}_{4}\right)$ besides their minerals $\left(\mathrm{CaF}_{2}, \mathrm{MgF}_{2}, \mathrm{FAP}\right.$, and CFAP).

Simultaneously, PC5 gives $10.92 \%$ of the total variance with positive and negative loadings which explains the relations between the physicochemical limits of the surface water, pore water, and sediment components, and the precipitation of minerals and salts (OCP, HAP, $\mathrm{CuBr}$, $\mathrm{Zn}(\mathrm{OH})_{2}$, and $\left.\mathrm{Zn}\left(\mathrm{IO}_{3}\right)_{2} \cdot 2 \mathrm{H}_{2} \mathrm{O}\right)$. This is also associated to the influence of the sedimentary material on the release of $\mathrm{Mn}, \mathrm{Fe}$, and $\mathrm{P}$ from sediment into pore water and water column and formation of $\mathrm{Ca}_{3}\left(\mathrm{PO}_{4}\right)_{2}$, OCP, and HAP minerals.

However, PC6 associates with $10.0 \%$ of the total variance giving positive and negative coefficient factor loadings, which explain that the sediments (minerals and/or organiciodine compounds) are only the acting sink for iodine and iodine species $\left(\mathrm{I}^{-}\right.$and $\left.\mathrm{IO}_{3}^{-}\right)$in the water as previously reported [84]. PC6 also reflects the precipitation of several halogenated compounds such as calcium iodate $\left(\mathrm{Ca}\left(\mathrm{IO}_{3}\right)_{2}\right.$ and $\left.\mathrm{Ca}\left(\mathrm{IO}_{3}\right)_{2} \cdot 6 \mathrm{H}_{2} \mathrm{O}\right)$ and copper iodate $(\mathrm{CuI}$ and $\left.\mathrm{CuIO}_{3} \cdot \mathrm{H}_{2} \mathrm{O}\right)$, besides $\mathrm{Cu}_{3}\left(\mathrm{PO}_{4}\right)_{2}$ species in the lake water column.
The loadings of PC7 contribute by $8.04 \%$ and show that the release of calcium in pore water into the water column is responsible for the precipitation of halogenated compounds $\left(\mathrm{CuCl}\right.$ and $\left.\mathrm{Zn}\left(\mathrm{IO}_{3}\right)_{2} \cdot 2 \mathrm{H}_{2} \mathrm{O}\right)$, as well as copper and $\mathrm{Zn}$ salts $\left(\mathrm{Cu}_{3}\left(\mathrm{PO}_{4}\right)_{2}\right.$, and $\left.\mathrm{Zn}(\mathrm{OH})_{2}\right)$.

3.6.2. Cluster Analysis. On the other hand, cluster analysis shows that the similarity of sites $1 \& 4,5 \& 8,6 \& 9,2 \& 10$, and $11 \& 13$ is due to the texture of sediment.

3.6.3. Multiple Regression. Multiple regression equations of halogens as dependent variables and the other determined and calculated parameters as independent variables in surface water, pore water, and sediment partitions are listed (Table 5). The amount of fluoride in water samples is affected by the discharged waters' fundamental components, especially $\mathrm{Zn}$ and $\mathrm{Cu}$, besides its surface water-pore water interactions. Its content in pore water seems to be strongly affected by its substitution competition with other halogens in surface water-spore water-sediment cycle due to its high electronegativity. Generally, in the affected area, the type of pollutant in the discharged water plays an important role in the dissolution and/or precipitation of fluoride and other halogens in the surface water-pore water-sediment cycle. 
TABLE 5: The multiple regression analyses of each halogen as dependent variable and other tested variables in the surface water, pore water, and sediment partitions, besides the precipitated salts in surface water along Lake Mariout.

\begin{tabular}{|c|c|c|}
\hline $\begin{array}{l}\text { Dependent } \\
\text { variable }\end{array}$ & Multiple regression equation & $R^{2}$ \\
\hline \multicolumn{3}{|l|}{ Fluoride } \\
\hline Lake water & $\mathrm{F}_{\mathrm{W}}=31.62+0.92 \mathrm{Zn} \mathrm{F}_{2}-0.33 \mathrm{Si}_{\mathrm{P}}+0.21 \mathrm{CuI}-0.17 \mathrm{~S} \% o_{\mathrm{P}}$ & 0.9911 \\
\hline Pore water & $\begin{array}{c}\mathrm{F}_{\mathrm{p}}=-25.67-1.17 \mathrm{Si}_{\mathrm{W}}-0.33 \mathrm{Li}_{\mathrm{P}}-0.62 \mathrm{CuCl}-0.28 \mathrm{I}_{\mathrm{S}}+0.23 \mathrm{TDS}_{\mathrm{W}}+0.17 \mathrm{KIO}_{4}-0.12 \mathrm{Br}_{\mathrm{W}}-0.04 \\
\text { porosity }+0.04 \mathrm{P}_{\mathrm{W}}\end{array}$ & 1.0000 \\
\hline Sediment & $\mathrm{F}_{\mathrm{S}}=0.88 \mathrm{CAP}-0.49 \mathrm{Mg}_{\mathrm{S}}-0.46 \mathrm{DO}_{\mathrm{W}}+0.39 \mathrm{Mg}_{\mathrm{W}}+0.27 \mathrm{Mn}\left(\mathrm{IO}_{3}\right)_{2}+0.15 \mathrm{Cu}_{3}\left(\mathrm{PO}_{4}\right)_{2}+0.04 \mathrm{HAP}+0.02 \mathrm{pH}_{\mathrm{P}}$ & 1.0000 \\
\hline \multicolumn{3}{|l|}{ Chloride } \\
\hline Lake water & No relation & 0.0000 \\
\hline Pore water & No relation & 0.0000 \\
\hline Sediment & $\mathrm{Cl}_{\mathrm{S}}=-1.16+0.46 \mathrm{Mg}_{\mathrm{P}}+0.77 \mathrm{~K}_{\mathrm{p}}-0.49$ dolomite $+0.17 \mathrm{TDS}_{\mathrm{W}}-0.11 \mathrm{CuI}+0.05 \mathrm{Na}_{\mathrm{S}}+0.02 \mathrm{~B}_{\mathrm{S}}+0.01 \mathrm{FeF}_{2}$ & 1.0000 \\
\hline \multicolumn{3}{|l|}{ Bromide } \\
\hline Lake water & $\mathrm{Br}_{\mathrm{W}}=156.3+1.10 \mathrm{CuBr}-0.57 \mathrm{CuCl}-0.21 \mathrm{~K}_{\mathrm{S}}-\underset{\text { turbidity }}{0.14 \mathrm{pH}_{\mathrm{P}}-0.11 \mathrm{TP}_{\mathrm{S}}+0.14 \mathrm{Fe}_{\mathrm{W}}+0.07 \mathrm{ZnS}-0.02 \mathrm{P}_{\mathrm{P}}+0.01}$ & 1.0000 \\
\hline Pore water & $\begin{array}{c}\mathrm{Br}_{\mathrm{P}}=-15.16-0.55 \mathrm{Fe}_{\mathrm{S}}-0.73 \mathrm{~B}_{\mathrm{S}}+0.61 \mathrm{Mn}_{\mathrm{W}}+0.83 \mathrm{Si}_{\mathrm{P}}+0.49 \mathrm{Na}_{\mathrm{S}}-0.31 \mathrm{Mn}_{\mathrm{S}}-0.15 \mathrm{CuBr}+0.11 \mathrm{pH} \mathrm{Ca}_{\mathrm{W}}-0.01 \\
\mathrm{Ca}\end{array}$ & 1.0000 \\
\hline Sediment & $\begin{array}{c}\mathrm{Br}_{\mathrm{S}}=0.15 \mathrm{Si}_{\mathrm{P}}+1.95 \mathrm{CFAP}+0.02 \mathrm{~F}_{\mathrm{P}}-0.45 \mathrm{I}_{\mathrm{S}}+1.92 \text { sand\% }+0.37 \mathrm{Mn}_{\mathrm{W}}-0.29 \mathrm{Mg}_{\mathrm{S}}-0.12 \mathrm{Li}_{\mathrm{P}}+0.05 \\
\mathrm{Ca}_{3}\left(\mathrm{PO}_{4}\right)_{2}-0.02 \mathrm{ZnF}_{2}\end{array}$ & 1.0000 \\
\hline \multicolumn{3}{|l|}{ Iodide } \\
\hline Lake water & $\mathrm{I}_{\mathrm{W}}=0.99 \mathrm{Ca}\left(\mathrm{IO}_{3}\right) \cdot 6 \mathrm{H}_{2} \mathrm{O}$ & 0.9999 \\
\hline water & $\begin{array}{c}\mathrm{I}_{\mathrm{P}}=-0.97 \mathrm{ZnF}_{2}-0.57 \mathrm{Li}_{3} \mathrm{PO}_{4}-0.53 \mathrm{~B}_{\mathrm{P}}+0.34 \mathrm{FAP}+0.15 \mathrm{Ca}\left(\mathrm{IO}_{3}\right)_{2}+\mathrm{Mn}_{\mathrm{W}}+0.05 \mathrm{~K}_{\mathrm{S}}-0.09 \text { turbidity }+0.55 \\
\mathrm{Ca}_{\mathrm{S}}\end{array}$ & 0.9999 \\
\hline Sediment & $\mathrm{I}_{\mathrm{S}}=-0.72+1.35 \mathrm{SO}_{4 \mathrm{P}}+0.23 \mathrm{Mn}\left(\mathrm{IO}_{3}\right)_{2}+0.63 \mathrm{Fe}_{\mathrm{W}}+0.31 \mathrm{TP}_{\mathrm{S}}-0.35 \mathrm{Mg}_{\mathrm{P}}-0.12 \mathrm{Zn}\left(\mathrm{CO}_{3}\right)_{2} .2 \mathrm{H}_{2} \mathrm{O}$ & 0.9993 \\
\hline
\end{tabular}

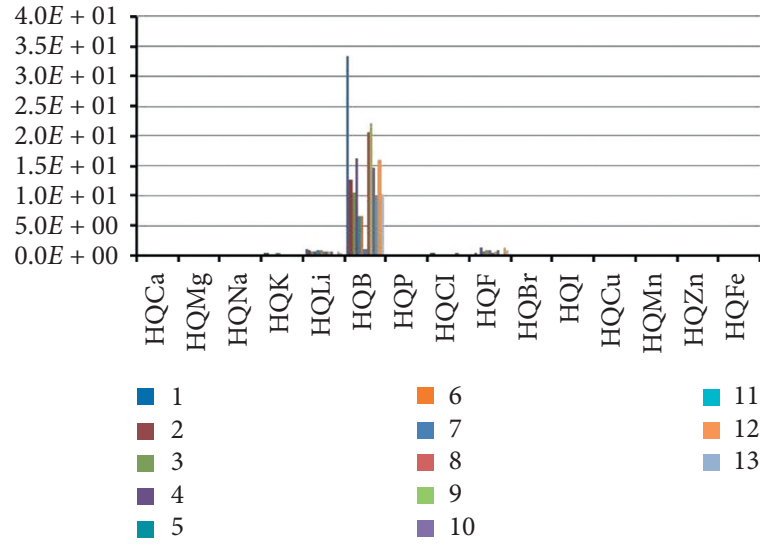

(a)

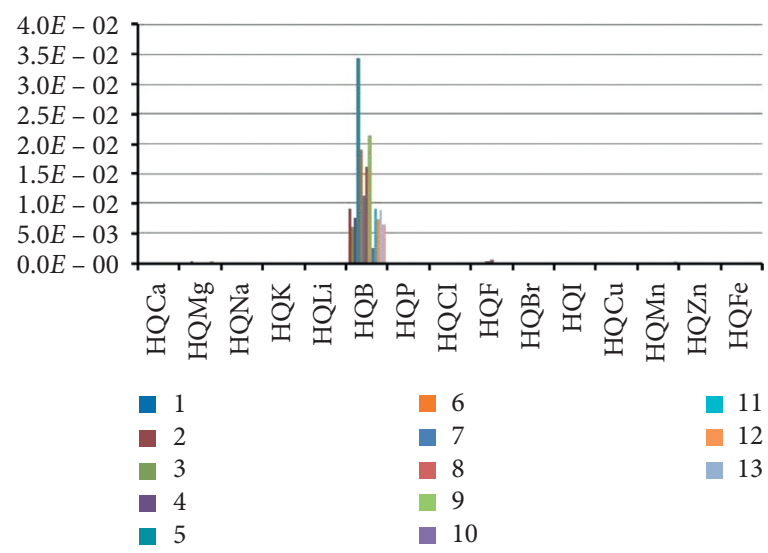

(c)

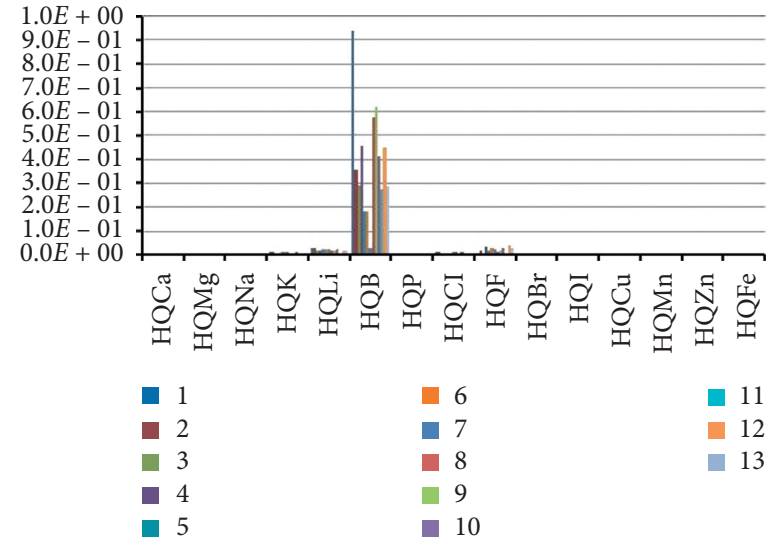

(b)

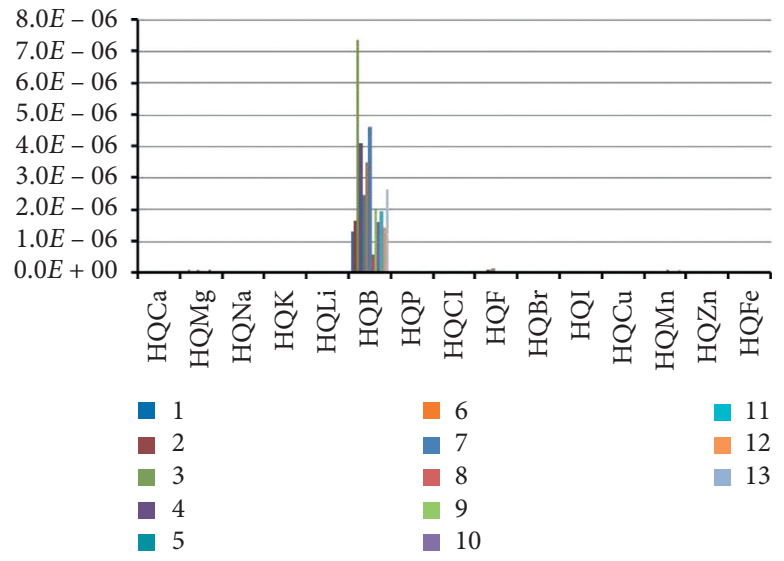

(d)

FiguRE 5: Hazard quotient of ingestion and dermal contact of surface water and sediment of Lake Mariout: (a) ingestion of water, (b) dermal contact of water, (c) ingestion of sediment, and (d) dermal contact of sediment. 


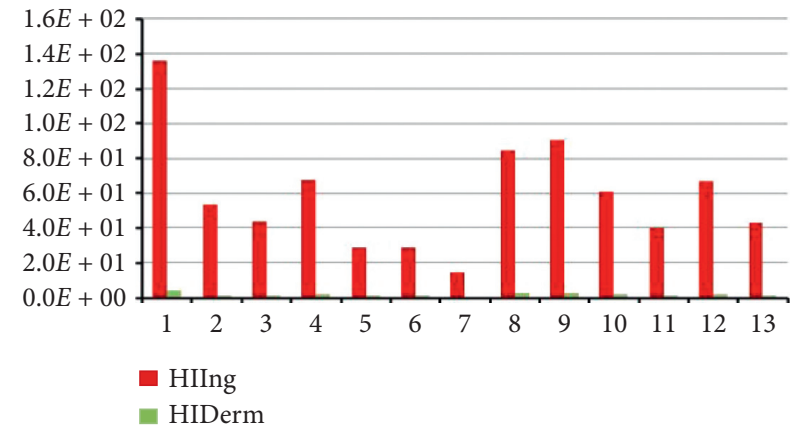

(a)

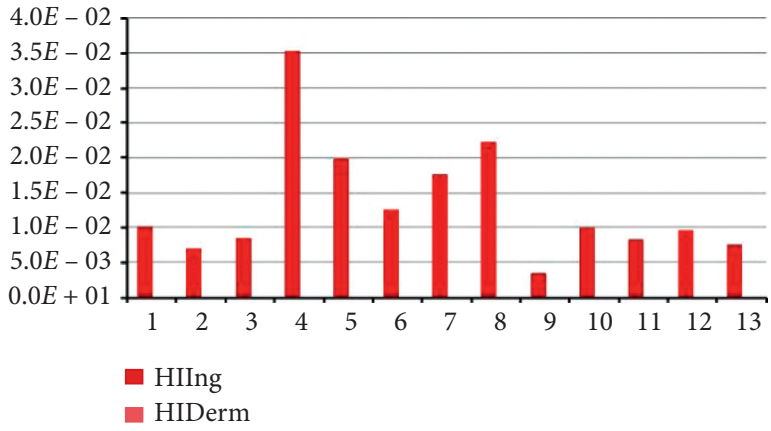

(b)

FiguRE 6: Hazard index of ingestion and dermal contact of the studied variables in surface water and sediment of Lake Mariout: (a) water and (b) sediment.

Minerals and precipitated salts in the different partitions (surface water, pore water, and sediment) play an important role in the deposition and release of halogens in sediments. Additionally, the texture and the porosity of the sediments play a key role in the distribution of halogens in the three partitions. Interestingly, chloride is the only halogen that has negligible interactions along the surface water and pore water partitions, because it is present in large quantities in the form of soluble salts $\left(\mathrm{NaCl}\right.$ and $\left.\mathrm{MgCl}_{2}\right)$.

\subsection{Pollution Status}

3.7.1. Enrichment Factor (EF). Two well-known methods are used to assess environmental pollution, public health significance of ingestion, and dermal contact with water and sediment components, and sediment enrichment factor (EF) $[59,60]$.

The average $\mathrm{EF}$ values of the determined elements $\mathrm{Ca}$, $\mathrm{Mg}, \mathrm{Na}, \mathrm{K}, \mathrm{Li}, \mathrm{B}, \mathrm{P}, \mathrm{Cu}, \mathrm{Zn}, \mathrm{Mn}, \mathrm{Fe}, \mathrm{F}, \mathrm{Cl}, \mathrm{Br}$, and I are all lower than the value that is less than the minimum enrichment value $(\mathrm{EF}<2)$. Thus, the area under investigation is still ecologically considered as an unpolluted region.

3.7.2. Human Health Risk Assessment. The EDI, HQ, and HI show the variable values of all pollutants in the surface water and sediments along the lake region and in drains (sites 11-13) under study. Among all the calculated variables of surface water ingestion $\left(\mathrm{EDI}_{\mathrm{Ingw}_{\mathrm{w}}}\right)$ and dermal contact $\left(\mathrm{EDI}_{\mathrm{Dermw}}\right), \mathrm{Cl}$ is still the only variable that shows high levels (average $=155.1$ and $4.3 \mathrm{mg} \mathrm{kg}^{-1}$ day $^{-1}$, respectively). The estimation daily intake of sediment ingestion $\left(\mathrm{EDI}_{\text {Ings }}\right)$ and dermal contact $\left(\mathrm{EDI}_{\text {Derms }}\right)$ of $\mathrm{Mg}, \mathrm{Ca}$, and $\mathrm{Na}$ give maximum average amounts of $8.41 E-02,5.13 E-02$, and $1.67 E-03 \mathrm{mg} \mathrm{kg}^{-1}$ day $^{-1}$, respectively.

Among the $\mathrm{HQ}$ of the calculated detection variables, the content of $\mathrm{HQ}_{B}$ of ingestion and dermal contact with water and sediment is the highest. However, $70 \%$ of sites have $\mathrm{HQ}_{B}$ values more than 10 (Figure 5). Comparing the HQ values of all the determined variables, $\mathrm{HQ}_{B}$ of the ingestion of surface water shows values higher $(>10)$. However, due to the impact of drainage, the $\mathrm{HQ}_{B}$ values of stations 1-4, 8-10, 12, and 13 are higher than 10 . Therefore, these sites can be considered as the area with the most serious boron pollution caused by untreated discharged water disposal. In addition, the $\mathrm{HI}_{\text {Ingw }}$ level of water ingestion for the studied variables in all sites is much higher than 10 (Figure 6). Except for boron, it is usually concluded that the study area does not pose any risk to the population due to halogens or other variables. Accordingly, this information may help the official authorities optimize management plans and strengthen their pollution control actions in Lake Mariout.

\section{Conclusions}

The effects of halogen salts and minerals on the pollution of Lake Mariout were studied. Halogens and some physicochemical variables in three partitions: surface water, pore water, and sediment in Lake Mariout were evaluated. The halogen content was variable between different sites, and chloride was the main halogen in surface water and pore water, but it was very rare in the lake's sediment partition. Piper ternary diagram, and Palmer's method reflected that $\mathrm{NaCl}$ was the dominant salt in surface water, while $\mathrm{MgCl}_{2}$ was the main dissolve salt in pore water. The chlorinity ratios of halogens and tested variables were directly matched to the feeding drain sources.

Moreover, the Saturation Index (SI) reveals that 23 and 15 precipitated salts and minerals are formed in surface water and pore water, respectively. The SI value indicated the formation of phosphate minerals in surface water and pore water, especially octacalcium phosphate (OCP; $\mathrm{Ca}_{4} \mathrm{H}\left(\mathrm{PO}_{4}\right)_{3} \cdot 2.5 \mathrm{H}_{2} \mathrm{O}$ ) and hydroxyapatite $\left(\mathrm{HAP} ; \mathrm{Ca}_{5}\left(\mathrm{PO}_{4}\right)_{3} \mathrm{OH}\right)$. In addition to fluoride minerals, especially fluorapatite (FAP) and carbonatefluorapatite (CFAP) were obviously precipitated from surface water and pore water. Soluble salts of bromide and chloride were formed in surface water and pore water. Iodide salts $\left(\mathrm{Ca}\left(\mathrm{IO}_{3}\right)_{2}\right.$ and $\left.\mathrm{Ca}\left(\mathrm{IO}_{3}\right)_{2} \cdot 6 \mathrm{H}_{2} \mathrm{O}\right)$ were moderately precipitated in the surface water and pore water.

Moreover, the multivariate analysis including the correlation matrix, multiple stepwise linear regression, tree clustering, and principle component (PCA) of all the determined and calculated variables was applied to estimate the proposed interaction between halogens and other tested 
variables in the polluted area under study. The multivariate analysis showed that there were many interactions between halogens and tested variables. High levels of fluoride, bromide, and chloride in surface water were related to the composition of drainage waters. The enrichment factor (EF) showed that Lake Mariout was not polluted. However, the human health adverse effects calculated for surface water and sediment did not reflect any possible likelihood hazard effects from halogens.

Interestingly, the current study concluded that halogen compounds, especially fluorides, are most likely to be deposited from surface lakes in the form of many minerals and precipitation, thereby reducing the adverse pollution effects on human health. The results obtained through this work help to find the correlations between the sampling sites and the variables obtained by physical and chemical measurements, which can be used to construct a fast decision model for separating different water quality samples. This information may help the official authorities optimize management plans and strengthen their pollution control measures in Lake Mariout.

\section{Data Availability}

The data used to support the findings of this research are included within the paper.

\section{Conflicts of Interest}

The authors declare that there are no conflicts of interest regarding the publication of this manuscript.

\section{Supplementary Materials}

Supplementary Table 1: correlation matrix of variable in surface water, pore water, and sediment partitions besides the precipitated salts in surface water along Lake Mariout. (Supplementary Materials)

\section{References}

[1] M. S. Masoud, T. O. Said, G. El-Zokm, and M. A. Shreadah, "Assesment of heavy metals contamination in surface sediments of the Egyptian Red Sea Coasts," Australian Journal of Basic and Applied Sciences, vol. 6, pp. 44-58, 2012.

[2] M. A. Shreadah, M. I. Abdel Moneim, T. O. Said, E. M. I. Fathallah, and M. E. Mahmoud, "PAHs in seawater of the semi-closed areas along the Alexandria coast of Egyptian Mediterranean sea," Journal of Environmental Protection, vol. 4, no. 11, p. 11, Article ID 40298, 2013.

[3] S. Abdel Ghani, G. El Zokm, A. Shobier, T. Othman, and M. Shreadah, "Metal pollution in surface sediments of AbuQir bay and Eastern harbour of Alexandria, Egypt," Egyptian Journal of Aquatic Research, vol. 39, no. 1, pp. 1-12, 2013.

[4] G. F. El-Said, "Bioaccumulation of key metals and other contaminants by seaweeds from the Egyptian Mediterranean Sea Coast in relation to human health risk," Human and Ecological Risk Assessment: An International Journal, vol. 19, no. 5, pp. 1285-1305, 2013.

[5] M. A. Shreadah, A. H. Shobier, S. Abdel Ghani, G. M. ElZokm, and T. O. Said, "Major ions anomalies and contamination status by trace metals in sediments from two hot spots along the Mediterranean Coast of Egypt," Environmental Monitoring and Assessment, vol. 187, no. 280, pp. 1-18, 2015.

[6] A. El Nemr, G. F. El-Said, A. Khaled, and S. Ragab, "Distribution and ecological risk assessment of some heavy metals in coastal surface sediments along the Red Sea, Egypt," International Journal of Sediment Research, vol. 31, no. 2, pp. 164-172, 2016.

[7] A. El Nemr, G. F. El-Said, S. Ragab, A. Khaled, and A. ElSikaily, "The distribution, contamination and risk assessment of heavy metals in sediment and shellfish from the Red Sea coast, Egypt," Chemosphere, vol. 165, pp. 369-380, 2016.

[8] A. El Nemr and G. F. El-Said, "Assessment and ecological risk of heavy metals in sediment and molluscs from the Mediterranean coast," Water Environment Research, vol. 89, no. 3, pp. 195-210, 2017.

[9] M. A. Sheradah, A. A. El-Sikaily, N. M. Abd El Moneam, N. E. Abd El Maguid, and M. G. Zaki, "Chemical and biochemical evaluation of marine pollution by polychlorinated biphenyls and pesticides in two regions along the Egyptian Mediterranean Sea," International Journal of Environmental Monitoring and Analysis, vol. 6, no. 3, pp. 95-109, 2018.

[10] M. A. Shreadah, A. A.-M. M. El-Sayed, A. A. S. Taha, A.-M. M. Ahmed, and H. H. Abdel Rahman, "Evaluation of different anthropogenic effluents impacts on the water quality using principal component analysis: a case study of Abu-Qir Bay-Alexandria-Egypt," International Journal of Environmental Monitoring and Analysis, vol. 7, no. 3, pp. 56-67, 2019.

[11] G. F. El-Said, M. M. El-Sadaawy, A. H. Shobier, and S. E. Ramadan, "Human health implication of major and trace elements present in commercial crustaceans of a traditional seafood marketing region, Egypt," Biological Trace Element Research, vol. 199, pp. 315-328, 2020.

[12] M. A. Shreadah, S. A. A. Ghani, H. B. I. Hawash, A. A. E. Samie, and A. E. M. M. Ahmed, "Organotin compounds in sediments of northern lakes, Egypt," Journal of Environmental Protection, vol. 05, no. 17, pp. 1654-1666, 2014.

[13] A. M. Younis, G. M. El-Zokm, and M. A. Okbah, "Spatial variation of acid-volatile sulfide and simultaneously extracted metals in Egyptian Mediterranean Sea lagoon sediments," Environmental Monitoring and Assessment, vol. 186, no. 6, pp. 3567-3579, 2014.

[14] G. F. El-Said, S. E. O. Draz, M. M. El-Sadaawy, and A. A. Moneer, "Sedimentology, geochemistry, pollution status and ecological risk assessment of some heavy metals in surficial sediments of an Egyptian lagoon connecting to the Mediterranean Sea," Journal of Environmental Science and Health, Part A, vol. 49, no. 9, pp. 1029-1044, 2014.

[15] G. M. El Zokm, M. A. Okbah, and A. M. Younis, "Assessment of heavy metals pollution using AVS-SEM and fractionation techniques in Edku Lagoon sediments, Mediterranean Sea, Egypt," Journal of Environmental Science and Health, Part A.vol. 50, no. 6, pp. 571-584, 2015.

[16] G. M. El Zokm, H. R. Z. Tadros, M. A. Okbah, and G. H. Ibrahim, “"Eutrophication assessment using TRIX and Carlson's indices in Lake Mariout water, Egypt," Egyptian Journal of Aquatic Biology and Fisheries, vol. 22, no. 5, pp. 331-349, 2018.

[17] N. Donia, "Lake Maryut monitoring using remote sensing," in Proceedings of the gypt Eighteenth International Water Technology Conference, IWTC18 Sharm El Sheikh, Abu Dhabi, UAE, March 2015. 
[18] M. A. Khairy, "Assessment of priority phenolic compounds in sediments from an extremely polluted coastal wetland (Lake Maryut, Egypt)," Environmental Monitoring and Assessment, vol. 185, no. 1, pp. 441-455, 2013.

[19] N. A. El-Naggar and E. A. Rifaat, "Egyptian coastal lakes and wetlands: part I-characteristics and hydrodynamics," in The Handbook of Environmental Chemistry, A. M. Negm, Ed., Springer International Publishing AG, Berlin, Germany, 2017.

[20] J. J. Hanley and K. T. Koga, "Chapter 2: "halogens in terrestrial and cosmic geochemical systems: abundances. Geochemical behaviors and analytical methods,"," in The Role of Halogens in Terrestrial and Extraterrestrial Geochemical Processes, D. E. Harlov and L. Aranovich, Eds., Springer International Publishing AG, Berlin, Germany, pp. 21-121, 2018.

[21] A. Ghosh, K. Mukherjee, S. K. Ghosh, and B. Saha, "Sources and toxicity of fluoride in the environment," Research on Chemical Intermediates, vol. 39, no. 7, pp. 2881-2915, 2013.

[22] M. M. Naim, A. A. Moneer, and G. F. El-Said, "Predictive equations for the defluoridation by electrocoagulation technique using bipolar aluminum electrodes in the absence and presence of additives: a multivariate study," Desalination and Water Treatment, vol. 57, no. 14, pp. 6320-6332, 2016.

[23] G. F. El-Said, N. A. Shaltout, M. M. El-Sadaawy, and A. M. H. Morsy, "The precipitation of fluoride, calcium and magnesium minerals from Egyptian Mediterranean Sea coast in relation to discharged waters," Desalination and Water Treatment, vol. 57, no. 5, pp. 2113-2124, 2016.

[24] H. Bureau, "Iodine, encyclopedia of geochemistry. A comprehensive reference source on the chemistry of the earth," in Encyclopedia of Earth Sciences Series, W. M. White, Ed., (C) Springer International Publishing AG, 2016.

[25] F. C. Küpper and C. J. Carrano, "Key aspects of the iodine metabolism in brown algae: a brief critical review," Metallomics, vol. 11, pp. 756-764, 2019.

[26] R. Liteplo, R. Gomes, P. Howe, and H. Malcolm, FluoridesEnvironmental Health Criteria 227, p. 290, World Health Organization (WHO), Geneva, Switzerland, 2002.

[27] G. F. El-Said and M. M. El-Sadaawy, "Seasonal variation of boron and fluoride in Tilapia nilotica from an Egyptian fish farm in relation to Human health hazard assessment," Human and Ecological Risk Assessment: An International Journal, vol. 19, no. 4, pp. 930-943, 2013.

[28] WHO (World Health Organization), Bromide in DrinkingWater Background Document for Development of WHO Guidelines for Drinking-Water Quality, WHO Press, World Health Organization, Geneva, Switzerland, 2009.

[29] G. F. El-Said and N. A. Sallam, "The uptake of fluoride concentration and its effects on the growth rate of shrimps (Palaemon elegans, Rathke)," Chemistry and Ecology, vol. 24, no. 3, pp. 191-205, 2008.

[30] X. Zhang, J. He, B. He, and J. Sun, “Assessment, formation mechanism, and different source contributions of dissolved salt pollution in the shallow groundwater of Hutuo River alluvial-pluvial fan in the North China Plain," Environmental Science and Pollution Research, vol. 26, no. 35, pp. 3574235756, 2019.

[31] Y. Zhu, B. Huang, Z. Zhu et al., "“'Characterization, dissolution and solubility of the hydroxypyromorphitehydroxyapatite solid solution $\left[\left(\mathrm{Pb}_{\mathrm{x}} \mathrm{Ca}_{1-\mathrm{x}}\right) 5\left(\mathrm{PO}_{4}\right)_{3} \mathrm{OH}\right]$ at $25{ }^{\circ} \mathrm{C}$ and pH 2-9," Geochemical Transactions, vol. 17, no. 2, pp. 1-18, 2016.

[32] G. F. El-Said, M. M. El-Sadaawy, A. A. Moneer, and N. A. Shaltout, "The effect of fluoride on the distribution of some minerals in the surface water of an Egyptian lagoon at the Mediterranean Sea," Egyptian Journal of Aquatic Research, vol. 41, no. 1, pp. 31-39, 2015.

[33] Y. Zhu, Z. Zhu, X. Zhao, Y. Liang, and Y. Huang, "Characterization, dissolution, and solubility of lead hydroxypyromorphite $[\mathrm{Pb} 5(\mathrm{PO} 4) 3 \mathrm{OH}]$ at $25-45^{\circ} \mathrm{C}$," Journal of Chemistry, vol. 2015, Article ID 269387, 10 pages, 2015.

[34] M. A. Z. Chahouki, "Multivariate analysis techniques in environmental science," in Earth and Environmental Sciences, Dr. Imran Ahmad Dar, Ed., InTech Open, London, UK, 2011, http://www.intechopen.com/books/earth-andenvironmental-sciences/multivariate-analysis-techniquesinenvironmental-science.

[35] J. V. Klump and C. S. Martens, "Biogeochemical cycling in an organic-rich coastal marine basin. 5. Sedimentary nitrogen and phosphorus budgets based upon kinetic models, mass balances, and the stoichiometry of nutrient regeneration," Geochimica et Cosmochimica Acta, vol. 51, no. 5, pp. 11611173, 1987.

[36] R. L. Folk, Petrology of Sedimentary Rocks, University of Texas, Austin, TX, USA, 1974.

[37] P. Saenger, "A rapid spectrophotometric method for the determination of bromine in seawater and in the ash of marine algae," Helgoländer Wissenschaftliche Meeresuntersuchungen, vol. 23, no. 1, pp. 32-37, 1972.

[38] P. G. Jeffery, Chemical Methods of Rock Analysis, Pergamon Press, New York, NY, USA, 2nd edition, 1975.

[39] J. D. H. Strickland and T. R. Parsons, "A practical handbook of seawater analysis," in Fisheries Research Board of Canada, Bulletin 167p. 311, Second edition, Wiley, Ottawa, Canada, 1972.

[40] B. Horváth, O. Opara-Nadi, and F. Beese, "A simple method for measuring the carbonate content of soils," Soil Science Society of America Journal, vol. 69, no. 4, pp. 1066-1068, 2005.

[41] K. Grasshoff, Methods of Seawater Analysis, p. 317, Verlag Chemie, Weinkeim, Germany, 1976.

[42] R. Danovaro, D. Marrale, N. Della Croce, P. Parodi, and M. Fabiano, "Biochemical composition of sedimentary organic matter and bacterial distribution in the Aegean Sea: trophic state and pelagic-benthic coupling," Journal of Sea Research, vol. 42, no. 2, pp. 117-129, 1999.

[43] APHA-AWWA-WPCF (American Public Health Association), Standard Methods for the Examination of Water and Waste Water, American Public Health Association, Washington, DC, USA, 20th edition, 1999.

[44] K. I. Aspila, H. Agemian, and A. S. Y. Chau, "A semi-automated method for the determination of inorganic, organic and total phosphate in sediments," The Analyst, vol. 101, no. 1200, pp. 187-197, 1976.

[45] J. P. Riley and D. Taylor, "Chelating resins for the concentration of trace elements from sea water and their analytical use in conjunction with atomic absorption spectrophotometry,” Analytica Chimica Acta, vol. 40, pp. 479-485, 1968.

[46] G. F. El-Said and A. El-Sikaily, "Chemical composition of some seaweed from Mediterranean Sea coast, Egypt," Environmental Monitoring and Assessment, vol. 185, no. 7, pp. 6089-6099, 2013.

[47] Directorate General of Health Services Ministry of Health and Family Welfare, Government of India, "Manual of methods of analysis of foods," in Fruit and Vegetable Productsp. 57, Directorate General of Health Services Ministry of Health and Family Welfare, Government of India, New Delhi, India, 2005.

[48] A. Gunnars, S. Blomqvist, and C. Martinsson, "Inorganic formation of apatite in brackish seawater from the Baltic Sea: 
an experimental approach," Marine Chemistry, vol. 91, no. 14, pp. 15-26, 2004.

[49] W. M. Haynes, D. R. Lide, and T. J. Bruno, CRC Handbook of Chemistry and Physics, A Ready Reference Book of Chemical and Physical Data, CRC Press, Taylor \& Frances Group, Boca Raton, FL, USA, 97th edition, 2017.

[50] M. S. Masoud, M. I. El-Samra, and M. M. El-Sadawy, "Water chemistry of el-mex bay, west of Alexandria, Egypt," The Egypian Science Magazine, vol. 2, pp. 70-78, 2005.

[51] F. J. Millero, R. Feistel, D. G. Wright, and T. J. McDougall, "The composition of standard seawater and the definition of the reference-composition salinity scale," Deep Sea Research Part I: Oceanographic Research Papers, vol. 55, no. 1, pp. 50-72, 2008.

[52] S. K. El-Wakeel, S. A. Morcos, and A. M. Mahlis, "The major cations in Lake Maryût waters," Hydrobiologia, vol. 36, no. 2, pp. 253-274, 1970.

[53] A. M. Mahlis, S. A. Morcos, and S. K. El-Wakeel, "The major anions in Lake Maryût waters," Hydrobiologia, vol. 36, no. 2, pp. 275-294, 1970.

[54] A. S. Saad, M. A. Massoud, R. A. Amer, and M. A. Ghorab, "Assessment of the physico-chemical characteristics and water quality analysis of Mariout Lake, southern of Alexandria, Egypt," Journal of Environmental and Analytical Toxicology, vol. 7, no. 1, p. 421, 2017.

[55] R. Rumuri, "Dataset on hydrogeochemical characteristics of groundwater and surface water in Kattumannarkoil Taluk, India," Data in Brief, vol. 32, Article ID 106058, 2020.

[56] P. Szefer, S. W. Fowler, K. Ikuta et al., "A comparative assessment of heavy metal accumulation in soft parts and byssus of mussels from subarctic, temperate, subtropical and tropical marine environments," Environmental Pollution, vol. 139, no. 1, pp. 70-78, 2006.

[57] N. F. Soliman, G. M. El Zokm, and M. A. Okbah, "Risk assessment and chemical fractionation of selected elements in surface sediments from Lake Qarun, Egypt using modified BCR technique," Chemosphere, vol. 191, pp. 262-271, 2018.

[58] G. M. El Zokm, M. I. A. Ibrahim, L. A. Mohamed, and M. ElMamoney, "Critical geochemical insight into Alexandria coast with special reference to diagnostic ratios (TOC/TN \& Sr/Ca) and heavy metals ecotoxicological hazards," Egyptian Journal of Aquatic Research, vol. 46, no. 1, pp. 27-33, 2020.

[59] A. S. Likuku, K. B. Mmolawa, and G. K. Gaboutloeloe, "Assessment of heavy metal enrichment and degree of contamination around the copper-nickel mine in the Selebi Phikwe Region, Eastern Botswana," Environment and Ecology Research, vol. 1, no. 2, pp. 32-40, 2013.

[60] M. K. Khalil, S. E. O. Draz, G. M. El Zokm, and G. F. El-Said, "Apportionment of geochemistry, texture's properties, and risk assessment of some elements in surface sediments from Bardawil Lagoon, Egypt," Human and Ecological Risk Assessment: An International Journal, vol. 22, no. 3, pp. 775-791, 2016.

[61] M. M. El-Sadaawy and G. F. El-Said, "Assessment of fluoride in three selected polluted environments along the Egyptian Mediterranean Sea: effects on local populations," Human and Ecological Risk Assessment: An International Journal, vol. 20, no. 6, pp. 1643-1658, 2014.

[62] USEPA, "Superfund exposure assessment manual," in OSWER Directive 9285.5-1.EPA/540/l-88/001Office of Emergency and Remedial Response, Washington, DC, USA, 1988.

[63] USEPA, "Exposure factors handbook," in EPA/600/8-89/ 043Office of Health and Environmental Assessment, Washington, DC, USA, 1989.
[64] Health Canada, "Federal Contaminated Site Risk Assessment in Canada" Part II: Health Canada Toxicological Reference Values (TRVs), Cat. H46-2/04-368E Calgary, Health Canada, Ottawa, Canada, 2007.

[65] J. Iqbal, S. A. Tirmizi, and M. H. Shah, "Statistical apportionment and risk assessment of selected metals in sediments from Rawal Lake (Pakistan)," Environmental Monitoring and Assessment, vol. 185, no. 1, pp. 729-743, 2013.

[66] USEPA (US Environmental Protection Agency), Region 6 USAEPA, "Multimedia Planning and Permitting Division," Office of Solid Waste, Center for Combustion Science and Engineering, Washington, DC, USA, 2005.

[67] P. Jeschke, "Latest generation of halogen-containing pesticides," Pest Management Science, vol. 73, no. 6, pp. 1053-1066, 2017.

[68] M. A. Shreadah, O. A. El-Rayis, N. A. Shaaban, and A. M. Hamdan, "Water quality assessment and phosphorus budget of a lake (Mariut, Egypt) after diversion of wastewaters effluents," Environmental Science and Pollution Research, vol. 27, no. 21, pp. 26786-26799, 2020.

[69] J. P. Riley and M. Tongudai, "The major cation/chlorinity ratios in sea water," Chemical Geology, vol. 2, pp. 263-269, 1967.

[70] R. B. McCleskey, D. K. Nordstrom, D. D. Susong, J. W. Ball, and J. M. Holloway, "Source and fate of inorganic solutes in the gibbon river, yellowstone national park, Wyoming, USA," Journal of Volcanology and Geothermal Research, vol. 193, no. 3-4, pp. 189-202, 2010.

[71] G. T. F. Wong and K.-Y. Li, "Winkler's method overestimates dissolved oxygen in seawater: iodate interference and its oceanographic implications," Marine Chemistry, vol. 115, no. 1-2, pp. 86-91, 2009.

[72] B. S. R. V. Prasad, P. D. N. Srinivasu, P. S. Varma, A. V. Raman, and S. Ray, "Dynamics of dissolved oxygen in relation to saturation and health of an aquatic body: a case for Chilka Lagoon, India," Journal of Ecosystems, vol. 2014, Article ID 526245, 17 pages, 2014.

[73] China Environmental Protection Agency, Environmental Quality Standards for Surface Water, (GB3838-2002), National Environmental Protection Agency of China, Beijing, China, 2002.

[74] Y. Jia, L. Wang, Z. Qu, and Z. Yang, "Distribution, contamination and accumulation of heavy metals in water, sediments, and freshwater shellfish from Liuyang River, Southern China," Environmental Science and Pollution Research, vol. 25, no. 7, pp. 7012-7020, 2018.

[75] A. Moneer, M. El-Sadawy, G. El-Said, and A. Radwan, "Boron human health risk assessment relative to the environmental pollution of Lake Edku, Egypt," Journal of King Abdulaziz University, vol. 23, no. 2, pp. 41-55, 2012.

[76] C. B. Tabelin, T. Igarashi, T. Arima, D. Sato, T. Tatsuhara, and S. Tamoto, "Characterization and evaluation of arsenic and boron adsorption onto natural geologic materials, and their application in the disposal of excavated altered rock," Geoderma, vol. 213, pp. 163-172, 2014.

[77] G. Aloisi, K. Wallmann, M. Drews, and G. Bohrmann, "Evidence for the submarine weathering of silicate minerals in Black Sea sediments: possible implications for the marine $\mathrm{Li}$ and B cycles," Geochemistry Geophysics Geosystems, vol. 5, no. 4, pp. 1-22, 2004.

[78] C. Degueldre and V. Cloet, "Pore water colloid properties in argillaceous sedimentary rocks," Science of The Total Environment, vol. 569-570, pp. 423-433, 2016. 
[79] J. A. Higgins and D. P. Schrag, "Records of Neogene seawater chemistry and diagenesis in deep-sea carbonate sediments and pore fluids," Earth and Planetary Science Letters, vol. 357358, pp. 386-396, 2012.

[80] H. Schroeder, A.-L. Fabricius, D. Ecker, T. A. Ternes, and L. Duester, "Metal(loid) speciation and size fractionation in sediment pore water depth profiles examined with a new meso profiling system," Chemosphere, vol. 179, pp. 185-193, 2017.

[81] Y. Song and G. Müller, "Freshwater sediments: sinks and sources of bromine," Naturwissenschaften, vol. 80, no. 12, pp. 558-560, 1993.

[82] M. E. Goher, H. I. Farhat, M. H. Abdo, and S. G. Salem, "Metal pollution assessment in the surface sediment of Lake Nasser, Egypt," Egyptian Journal of Aquatic Research, vol. 40, no. 3, pp. 213-224, 2014.

[83] G. F. El-Said, M. M. El-Sadawy, and A. A. Moneer, "Incorporation of fluoride and boron into surface sediments along the Egyptian Mediterranean coast," Egyptian Journal of Aquatic Research, vol. 36, no. 4, pp. 569-583, 2010.

[84] B. Gilfedder, G. M. Petri, M. Wessels, and H. Biester, "An iodine mass-balance for Lake Constance, Germany: insights into iodine speciation changes and fluxes," Geochimica et Cosmochimica Acta, vol. 74, no. 11, pp. 3090-3111, 2010.

[85] E. Korobova, L. Kolmykova, B. Ryzhenko et al., "Distribution and speciation of iodine in drinking waters from geochemically different areas of Bryansk region contaminated after the Chernobyl accident in relation to health and remediation aspects," Journal of Geochemical Exploration, vol. 184, pp. 311-317, 2018.

[86] V. Žic, V. W. Truesdale, and N. Cukrov, "The distribution of iodide and iodate in anchialine cave waters-evidence for sustained localised oxidation of iodide to iodate in marine water," Marine Chemistry, vol. 112, no. 3-4, pp. 168-178, 2008.

[87] M. B. Heeb, J. Criquet, S. G. Zimmermann-Steffens, and U. Von Gunten, "Oxidative treatment of bromide-containing waters: formation of bromine and its reactions with inorganic and organic compounds-a critical review," Water Research, vol. 48, pp. 15-42, 2014.

[88] V. Sivasankar, A. K. Darchen, and R. Omine Sakthivel, "Chapter 2: "fluoride: a world ubiquitous compound, its chemistry, and ways of contamination," in Surface Modified Carbons as Scavengers for Fluoride from Water, V. Sivasankar, Ed., pp. 5-32, (c) Springer International Publishing Switzerland, Cham, Switzerland, 2016.

[89] Ó. Cabestrero, P. Del Buey, and M. E. Sanz-Montero, "Biosedimentary and geochemical constraints on the precipitation of mineral crusts in shallow sulphate lakes," Sedimentary Geology, vol. 366, pp. 32-46, 2018.

[90] M. A. Hassaan, O. A. El-Rayis, and E. I. Hemada, "Estimation of the redox potential of lake mariut drainage system (Qalaa and Umum drains)," Hydrology, vol. 5, no. 6, pp. 82-85, 2017. 